Review Article

\title{
Osteogenic Potential of Dental Mesenchymal Stem Cells in Preclinical Studies: A Systematic Review Using Modified ARRIVE and CONSORT Guidelines
}

\author{
Murali Ramamoorthi, ${ }^{1}$ Mohammed Bakkar, ${ }^{1,2}$ Jack Jordan, ${ }^{1}$ and Simon D. Tran ${ }^{1}$ \\ ${ }^{1}$ Craniofacial Tissue Engineering and Stem Cells Laboratory, Faculty of Dentistry, McGill University, Montreal, QC, Canada
}

${ }^{2}$ King Fahad Armed Forces Hospital, Jeddah, Saudi Arabia

Correspondence should be addressed to Simon D. Tran; simon.tran@mcgill.ca

Received 27 November 2014; Accepted 1 February 2015

Academic Editor: Long Bi

Copyright (C) 2015 Murali Ramamoorthi et al. This is an open access article distributed under the Creative Commons Attribution License, which permits unrestricted use, distribution, and reproduction in any medium, provided the original work is properly cited.

\begin{abstract}
Background and Objective. Dental stem cell-based tissue engineered constructs are emerging as a promising alternative to autologous bone transfer for treating bone defects. The purpose of this review is to systematically assess the preclinical in vivo and in vitro studies which have evaluated the efficacy of dental stem cells on bone regeneration. Methods. A literature search was conducted in Ovid Medline, Embase, PubMed, and Web of Science up to October 2014. Implantation of dental stem cells in animal models for evaluating bone regeneration and/or in vitro studies demonstrating osteogenic potential of dental stem cells were included. The preferred reporting items for systematic reviews and meta-analyses (PRISMA) guidelines were used to ensure the quality of the search. Modified ARRIVE (Animal research: reporting in invivo experiments) and CONSORT (Consolidated reporting of trials) were used to critically analyze the selected studies. Results. From 1914 citations, 207 full-text articles were screened and 137 studies were included in this review. Because of the heterogeneity observed in the studies selected, meta-analysis was not possible. Conclusion. Both in vivo and in vitro studies indicate the potential use of dental stem cells in bone regeneration. However welldesigned randomized animal trials are needed before moving into clinical trials.
\end{abstract}

\section{Introduction}

Bone is a multifunctional organ that provides protection, structure, and mechanical support to the body [1]. The integrity of human bone is challenged by infections, trauma, congenital malformation, and surgical removal of tumor [24]. Repair and regeneration of bone are a series of biological events involving a number of cell types and signaling pathways in a temporal and spatial sequence [2-6]. When these natural mechanisms/events are compromised, bone grafting is commonly used to augment bone repair and regeneration. Autologous bone grafting has been considered as a "gold standard" because it possesses osteogenesis (osteoprogenitor cells), osteoinduction (BMPs, growth factors), and osteoconduction (scaffold) [7]. However, limitations such as a limited supply, resorption, donor site morbidity, deformity, chronic infection, and rejection demand other alternative treatment approaches $[7,8]$.
Cell-based bone tissue engineering emerges as a potential alternative as it aims to generate new cell-driven, functional tissue rather than to fill a defect with a nonliving scaffold. It is a combination of principles of orthopedic surgery with biology, physics, material science, and engineering [7]. Classic bone tissue engineering is comprised of osteogenic cells (to form bone tissue matrix), morphogenic signals (help the cells to be the desired phenotype), biocompatible scaffold (to mimic an extracellular matrix niche), and vascular supply (to meet the nutrient supply and clearance of the growing tissue) $[7,8]$. Stem cells play a pivotal role in bone tissue engineering [9-15].

Multipotent mesenchymal stromal cells (commonly referred to as mesenchymal stem cells, MSCs) are the most frequently used cell population in tissue engineering because of its multilineage potential, multiple sources, and ability to self-renew $[16,17]$. Bone marrow-derived mesenchymal stem cells (BMMSCs) are being considered as a gold standard 
$[7,9,16,17]$. However, because of the difficulty to harvest a sufficient cell number as well as the pain and morbidity involved during the harvesting procedure, researchers have been exploring other sources/locations for MSCs. Many anatomical locations have been researched to yield MSC populations $[1,7,18,19]$. One of the potential sources identified was the dental/oral tissues. Research on using MSCs of dental origin has increased exponentially in the last decade [20-22].

Dental stem/progenitor cells were isolated, characterized, and categorized into six major types [22, 23]: (1) dental pulpderived stem cells/postnatal dental pulp stem cells (DPSCs), (2) stem cell from exfoliated human dentition (SHED), (3) stem cell from the apical papilla (SCAP), (4) periodontal ligament-derived stem cells (PDLSCs), (5) dental folliclederived stem cells (DFSCs), and (6) gingival mesenchymal stem cells (GMSCs). The major attractions towards using dental MSCs are ease of access, less invasive approach for harvest, ability to produce higher colony forming units (CFUs), and a higher cell proliferation rate and survival time than bone marrow-derived MSCs [24, 25].

A significant body of literature has been published in the past five years on various types of dental MSCs and its applications [24]. However, there is still limited evidence regarding the capacity of dental MSCs for bone regeneration. An in-depth review and understanding of preclinical in vitro and in vivo studies is a prerequisite to assess the efficacy of dental MSCs and to translate their use into the clinics [26]. Thus the aim of this paper is to perform a systematic review of the literature on dental MSCs for bone regeneration, including in vitro and in vivo studies.

\section{Materials and Methods}

2.1. Review Protocol. We focused our review question to address: "Do dental-derived stem cells possess osteogenic potential and regenerate bone defects in in vitro and in animal models"?

2.2. Search Strategy. A comprehensive literature search published up to September 2014 was performed on the article databases: Ovid Medline, Embase, PubMed, and Web of Science. The search strategy used a combination of medical subject headings (MeSH) terms and keywords for Medline, PubMed, Web of Science, and EMBASE. The keywords and MeSH terms used for the search were stem cells, mesenchymal stromal cells, progenitor cells, tooth, dental pulp, dental sac, periodontal ligament, deciduous tooth, neural crest, gingiva, SCAP, DPSC, DFSC, GMSC, PDLSC, SHED, bone repair, bone regeneration, bone transplantation, bone substitute, bone tissue engineering, tissue engineering, bone reconstruction, bone defect, osteogenesis, tissue scaffolds, bioreactor, bone morphogenetic protein, intercellular signaling peptide, in vitro, in vivo, animal model, and preclinical. In addition, a hand search strategy was performed by the authors from the citation/reference list of the primary studies and reviews.

\subsection{Outcomes Measure}

(i) Osteogenic potential/calcified nodule formation/mineralized tissue formation with evidence of osteocyte/osteoblast confirmed by either histology or alkaline phosphatase (ALP) assay or histochemical staining for in vitro studies.

(ii) New bone formation/bone regeneration/defect closure/defect bridging/hard tissue formation (bone)/ mineralized tissue or calcified tissue (evidence of osteoblast/osteocyte) confirmed at least by histology or radiography for in vivo studies.

2.4. Inclusion Criteria. The selection was limited to the studies which should have

(i) used at least one type of stem cell derived from dental tissue,

(ii) studied either osteogenic potential or bone regeneration,

(iii) evaluated at least one of the outcomes mentioned above.

2.5. Exclusion Criteria. Studies those used Mesenchymal stem cells derived from mandibular bone, maxillary bone, palatal bone, alveolar bone, buccal mucosa. Conference proceedings, abstracts, expert opinion, and letters were excluded from the initial search phase. The manual examination of titles and abstracts further excluded studies that did not meet the inclusion criteria. Odontogenic/periodontal ligament/cementum/dentin regeneration systematic reviews, clinical studies, and non-English articles were omitted after the proofreading of full-text articles.

2.6. Screening Methods and Data Extraction. The studies were selected and screened by two authors (Murali Ramamoorthi and Mohammed Bakkar). Disagreements between the reviewers were resolved by consensus with all the authors. Data were extracted based on authors, year of publication, population characteristics (animal species, gender, age, weight, number of animals, stem cell source, intervention, defect location and dynamics, scaffold/carrier/cues, period of observation, and evaluation methods) for in vivo studies, experimental characteristics (stem cell source, osteogenic medium, scaffold/carrier/cues, and evaluation methods) for in vitro studies, and methodological characteristics (study quality/risk bias assessment) for both in vivo and in vitro studies.

2.7. Study Quality Assessment. As there are no established sets of criteria/guidelines for assessing the quality or risk of bias for in vivo and in vitro studies [27-32], we assessed the quality of all selected full-text articles using the ARRIVE (animal research: reporting in in vivo experiments) guidelines [27] for in vivo and a modified ARRIVE combined with CONSORT (consolidated reporting of trials) guidelines for in vitro experiments, based on the previous studies [25, 26, 28-30]. The evaluation was based on a predefined grading system of 


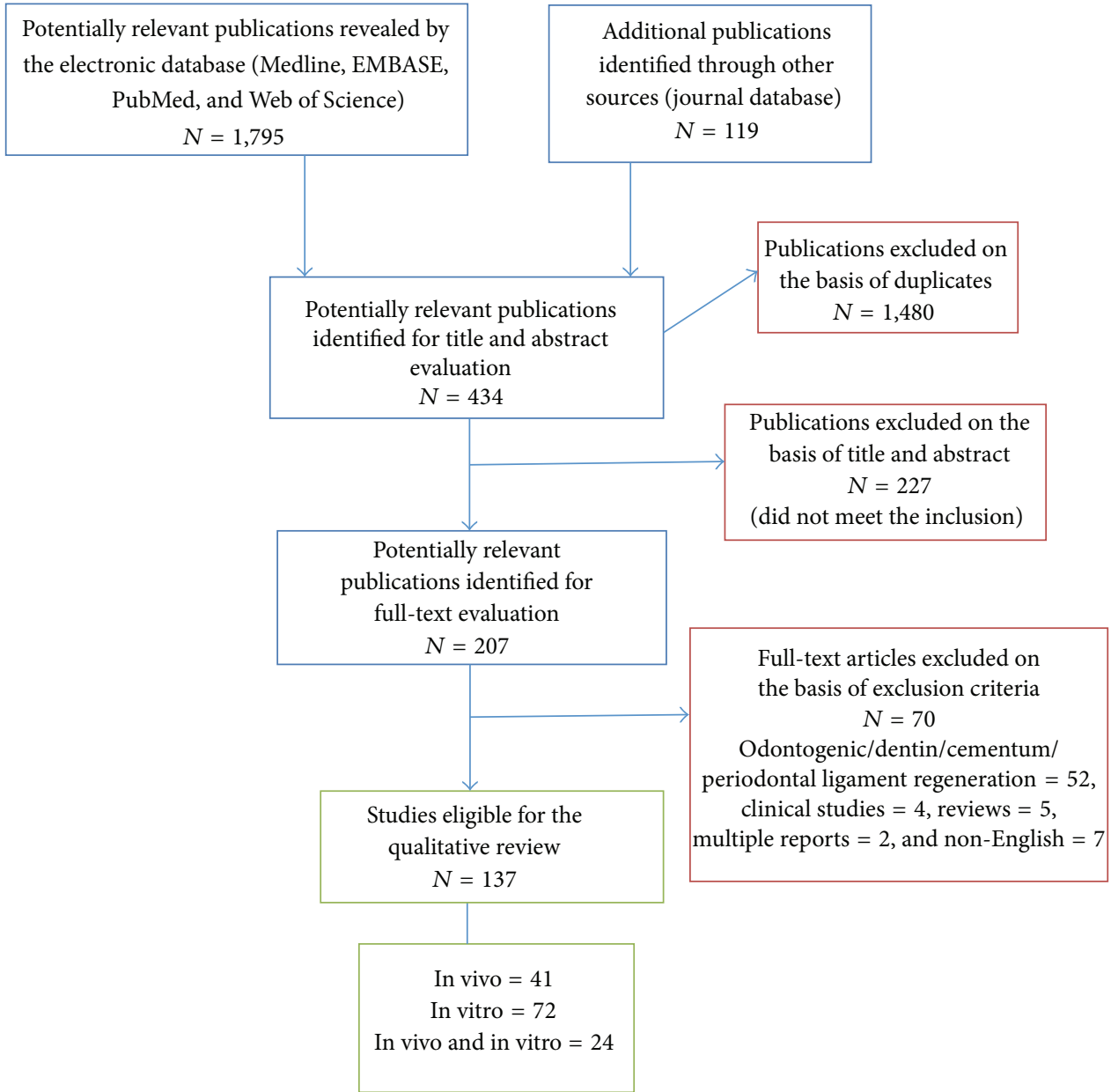

FIGURE 1: Flow chart demonstrating the strategy used to identify in vitro and in vivo studies for this systematic review of dental stem cells on bone regeneration (PRISMA guidelines is used to design this search strategy).

the checklist for in vitro studies (Table 1) and (Table 2) for in vivo studies.

The quality of the articles was assessed by the authors using a checklist of ARRIVE (animal research: reporting in in vivo experiments) guidelines for in vivo studies and using modified ARRIVE and CONSORT (consolidated reporting of trials) guidelines for in vitro studies (the evaluation was based on predefined grading system) (Table 2).

Risk of bias is commonly used to assess clinical trials. Thus we included a risk of bias assessment, as suggested by Bright et al. [25] and the Cochrane Review handbook to improve the quality of our review on dental MSCs. The parameters used were (i) power calculation to determine the samples, (ii) allocation concealment, randomization/replication/multiple experiments done to show consistency, and (iii) blinding in allotment/evaluation of results. A simple Yes or No was used to score selected articles, based on these parameters above.

2.8. Statistical Analysis. Because of heterogeneity of sources of dental MSCs, different animal species, diverse defect characteristics, various evaluation times, and different scaffolds/cues among our selected 137 articles, a (statistical) metaanalysis for quantitative review was not possible. We were able to perform a qualitative systematic review.

\section{Results}

3.1. Search Results. A total of 1,914 articles were retrieved from the literature search; 1,480 were excluded because of duplication. Four hundred and thirty-four articles were eligible for title and abstract screening. 227 articles were excluded as they did not meet the inclusion criteria. Thus 207 articles were qualified for full-text evaluation. 70 articles were excluded after proofreading the full text. The reasons for exclusion were as follows: odontogenic/dentin/cementum/ periodontal ligament regeneration $(n=52)$, clinical studies $(n=4)$, reviews $(n=5)$, language restrictions $(n=7)$, and multiple reports of the same experiment $(n=2)$, thus leaving 137 full articles to be included in this systematic qualitative review. The outline of articles selection is summarized in a flow chart (Figure 1). The details of the included studies are described in Table 3. 
TABLE 1: Categories used to assess the quality of selected in vitro studies (modified from the ARRIVE and CONSORT guidelines) [26].

\begin{tabular}{|c|c|c|}
\hline Item & Description & Grade \\
\hline 1 & Title & $\begin{array}{l}\text { (0) Inaccurate/nonconcise } \\
\text { (1) Concise/adequate }\end{array}$ \\
\hline 2 & $\begin{array}{l}\text { Abstract: either a structured summary of background, } \\
\text { research objectives, key experiment methods, principal } \\
\text { findings, and conclusion of the study or self-contained } \\
\text { (should contain enough information to enable a good } \\
\text { understanding of the rationale for the approach) }\end{array}$ & $\begin{array}{l}\text { (1) Clearly inadequate } \\
\text { (2) Possibly accurate } \\
\text { (3) Clearly accurate }\end{array}$ \\
\hline 3 & $\begin{array}{l}\text { Introduction: background, experimental approach, and } \\
\text { explanation of rationale/hypothesis }\end{array}$ & $\begin{array}{l}\text { (1) Insufficient } \\
\text { (2) Possibly sufficient/some } \\
\text { information } \\
\text { (3) Clearly meets/sufficient }\end{array}$ \\
\hline 4 & $\begin{array}{l}\text { Introduction: preprimary and secondary objectives for the } \\
\text { experiments (specific primary/secondary objectives) }\end{array}$ & $\begin{array}{l}\text { (1) Not clearly stated } \\
(2) \text { Clearly stated }\end{array}$ \\
\hline 5 & $\begin{array}{l}\text { Methods: study design explained number of experimental } \\
\text { and control groups, steps to reduce bias (demonstrating the } \\
\text { consistency of the experiment (done more than once), } \\
\text { sufficient detail for replication, blinding in evaluation, etc.) }\end{array}$ & $\begin{array}{l}\text { (1) Clearly insufficient } \\
\text { (2) Possibly sufficient } \\
\text { (3) Clearly sufficient }\end{array}$ \\
\hline 6 & $\begin{array}{l}\text { Methods: precise details of experimental procedure (i.e., how, } \\
\text { when, where, and why) }\end{array}$ & $\begin{array}{l}\text { (1) Clearly insufficient } \\
\text { (2) Possibly sufficient } \\
\text { (3) Clearly sufficient }\end{array}$ \\
\hline 7 & $\begin{array}{l}\text { Methods: How sample size was determined (details of control } \\
\text { and experimental group) and sample size calculation. }\end{array}$ & $\begin{array}{l}\text { (1) No } \\
\text { (2) Unclear/not complete } \\
\text { (3) Adequate/clear }\end{array}$ \\
\hline 8 & $\begin{array}{l}\text { Methods: Details of statistical methods and analysis } \\
\text { (statistical methods used to compare groups) }\end{array}$ & $\begin{array}{l}\text { (1) No } \\
\text { (2) Unclear/not complete } \\
\text { (3) Adequate/clear }\end{array}$ \\
\hline 9 & $\begin{array}{l}\text { Results: explanation for any excluded data, results of each } \\
\text { analysis with a measure of precision as standard deviation or } \\
\text { standard error or confidence interval }\end{array}$ & $\begin{array}{l}\text { (1) No } \\
\text { (2) Unclear/not complete } \\
\text { (3) Adequate/clear }\end{array}$ \\
\hline 10 & $\begin{array}{l}\text { Discussion: interpretation/scientific implication, limitations, } \\
\text { and generalizability/translation }\end{array}$ & $\begin{array}{l}\text { (0) Clearly inadequate } \\
\text { (1) Possibly accurate } \\
\text { (2) Clearly accurate }\end{array}$ \\
\hline 11 & Statement of potential conflicts and funding disclosure & $\begin{array}{l}\text { (0) No } \\
\text { (1) Yes }\end{array}$ \\
\hline 12 & Publication in a peer-review journal & $\begin{array}{l}\text { (0) No } \\
\text { (1) Yes }\end{array}$ \\
\hline
\end{tabular}

3.2. Characteristics of the Selected Studies. Out of 137 articles, $80.5 \%$ of the studies were published between 2010 and September 2014. Dental pulp-derived (35.5\%) and periodontal ligament-derived (30.4\%) stem cells were more predominantly studied among the eight different dental sources of stem cells reported in this review. Detailed characteristics (year, source, species, scaffolds/cues, medium, transplanted cell number, evaluation methods, and conclusion of the study) of these studies are shown in Tables 4 and 5.

Five different species of animals (rat/mice, dog, minipig, rabbit, and sheep) were used for the in vivo experiments. A total of 704 animals were used to study the osteogenic potential/bone regeneration of dental stem cells. Out of 65 in vivo studies, 46 used either rats or mice, 13 used dogs, two used minipigs, three used rabbits, and one used sheep to transplant dental stem cells. In 39 out of 65 studies, the dental stem cell source was from humans. Then 13 studies used dental MSCs from dogs, seven from a rat source, two from rabbits, two from minipigs, one from porcine, and one from sheep. The defect type and location were not uniform. Twentyfour studies used subcutaneous implantation on animals, 12 in periodontal defects, nine in mandibular defects, seven in critical-size defects of the calvarium, three in the renal capsule, and one in maxillary sinus augmentation as a defect model to observe osteogenic potential or bone formation in vivo.

In the selected in vitro studies, 85 of the 96 studies used dental MSCs from humans. The remaining 11 studies obtain dental stem cells from rats (7), porcine (1), dog (1), chimpanzee (1), and macaque nemestrima (1). Four in vitro studies used a bioreactor in their experiments. Ninety studies used osteogenic induction medium with serum, while four studies used serum-free medium and two studies used human serum. Nine in vitro studies and five in vivo studies compared the osteogenic potential of different dental derived stem cells. Most of the studies compared the osteogenic potential of 
TABLE 2: Categories used to assess the quality of selected in vivo studies (based on the ARRIVE guidelines).

\begin{tabular}{|c|c|c|}
\hline Item & Description & Grade \\
\hline 1 & Title & $\begin{array}{l}\text { (0) Inaccurate/nonconcise } \\
\text { (1) Concise/adequate }\end{array}$ \\
\hline 2 & $\begin{array}{l}\text { Abstract: either a structured summary of background, research objectives, key } \\
\text { experiment methods, principal findings, and conclusion of the study or enough } \\
\text { information to enable good understanding of the rationale for the approach } \\
\text { (self-contained) }\end{array}$ & $\begin{array}{l}\text { (1) Clearly inadequate } \\
\text { (2) Possibly accurate } \\
\text { (3) Clearly accurate }\end{array}$ \\
\hline 3 & Introduction: background, experimental approach, and rationale & $\begin{array}{l}\text { (0) Insufficient } \\
\text { (1) Possibly sufficient/some information } \\
\text { (2) Clearly meets/sufficient }\end{array}$ \\
\hline 4 & Introduction: primary and secondary objectives & $\begin{array}{l}\text { (0) Not clearly stated } \\
\text { (1) Clearly stated }\end{array}$ \\
\hline 5 & $\begin{array}{l}\text { Methods: ethical statement (nature of the review permission, relevant license, } \\
\text { and national guidelines for the care and use of animals) }\end{array}$ & $\begin{array}{l}\text { (1) Clearly insufficient } \\
\text { (2) Possibly sufficient } \\
\text { (3) Clearly sufficient }\end{array}$ \\
\hline 6 & $\begin{array}{l}\text { Methods: study design explained number of experimental and control groups, } \\
\text { steps to reduce bias by allocation concealment, randomization, and binding }\end{array}$ & $\begin{array}{l}\text { (1) Clearly insufficient } \\
\text { (2) Possibly sufficient } \\
\text { (3) Clearly sufficient }\end{array}$ \\
\hline 7 & $\begin{array}{l}\text { Methods: precise details of experimental procedure (i.e., how, when, where, and } \\
\text { why) }\end{array}$ & $\begin{array}{l}\text { (0) Clearly insufficient } \\
\text { (1) Possibly sufficient } \\
\text { (2) Clearly sufficient }\end{array}$ \\
\hline 8 & $\begin{array}{l}\text { Methods: experimental animal species, strains, sex, development stage, weight, } \\
\text { and source of animals }\end{array}$ & $\begin{array}{l}\text { (1) Clearly insufficient } \\
\text { (2) Possibly sufficient } \\
\text { (3) Clearly sufficient }\end{array}$ \\
\hline 9 & $\begin{array}{l}\text { Methods: housing and husbandry conditions (welfare related assessments and } \\
\text { interventions include type of cage, bedding material, number of cage } \\
\text { companions, temperature, light or dark cycle, and access to food and water) }\end{array}$ & $\begin{array}{l}\text { (1) Clearly insufficient } \\
\text { (2) Possibly sufficient } \\
\text { (3) Clearly sufficient }\end{array}$ \\
\hline 10 & $\begin{array}{l}\text { Methods: total number of animals used in each experimental group and sample } \\
\text { size calculation }\end{array}$ & $\begin{array}{l}\text { (1) No } \\
\text { (2) Unclear/not complete } \\
\text { (3) Adequate/clear }\end{array}$ \\
\hline 11 & $\begin{array}{l}\text { Methods: allocation animals to experimental groups (randomization or } \\
\text { matching), order in which animals were treated and assessed }\end{array}$ & $\begin{array}{l}\text { (1) No } \\
\text { (2) Yes }\end{array}$ \\
\hline 12 & $\begin{array}{l}\text { Methods: outcomes (clearly defines the experimental methods to evaluate the } \\
\text { prespecified outcomes) }\end{array}$ & $\begin{array}{l}\text { (1) No } \\
\text { (2) Unclear/not complete } \\
\text { (3) Clear/complete }\end{array}$ \\
\hline 13 & Methods: details of statistical methods and analysis & $\begin{array}{l}\text { (0) No } \\
\text { (1) Unclear/not complete } \\
\text { (2) Adequate/clear }\end{array}$ \\
\hline 14 & Results: baseline data (characteristic and health status of animals) & $\begin{array}{l}\text { (0) No } \\
\text { (1) Yes }\end{array}$ \\
\hline 15 & Results: numbers analyzed and explanation for any excluded & $\begin{array}{l}\text { (0) No } \\
\text { (1) Unclear/not complete } \\
\text { (2) Adequate/clear }\end{array}$ \\
\hline 16 & $\begin{array}{l}\text { Results for each analysis with a measure of precision as standard error or } \\
\text { confidence interval }\end{array}$ & $\begin{array}{l}\text { (1) No } \\
\text { (2) Unclear/not complete } \\
\text { (3) Yes }\end{array}$ \\
\hline 17 & Adverse events details and modification for reduction & $\begin{array}{l}\text { (0) No } \\
\text { (1) Unclear/not complete } \\
\text { (2) Yes }\end{array}$ \\
\hline 18 & $\begin{array}{l}\text { Discussion: interpretation/scientific implication, limitations including animal } \\
\text { model, implication for the } 3 \text { Rs (replacement, reduction, and refinement) }\end{array}$ & $\begin{array}{l}\text { (1) Clearly inadequate } \\
\text { (2) Possibly accurate } \\
\text { (3) Clearly accurate }\end{array}$ \\
\hline 19 & Discussion: generalizability/translation & $\begin{array}{l}\text { (0) Clearly inadequate } \\
\text { (1) Possibly adequate } \\
\text { (2) Clearly adequate }\end{array}$ \\
\hline 20 & Statement of potential conflicts and funding disclosure & $\begin{array}{l}\text { (0) No } \\
\text { (1) Unclear/not complete } \\
\text { (2) Yes }\end{array}$ \\
\hline
\end{tabular}


TABLE 3: The details and number of studies included in this qualitative review.

\begin{tabular}{lccc}
\hline $\begin{array}{l}\text { Dental stem cell } \\
\text { source }\end{array}$ & In vivo & In vitro & $\begin{array}{c}\text { Both in vivo and in } \\
\text { vitro }\end{array}$ \\
\hline $\begin{array}{l}\text { Dental papilla } \\
\text { Apical papilla }\end{array}$ & 0 & 1 & 0 \\
$\begin{array}{l}\text { Dental follicle } \\
\text { Neural crest }\end{array}$ & 1 & 4 & 4 \\
$\begin{array}{l}\text { Gingiva } \\
\begin{array}{l}\text { Dental pulp of } \\
\text { exfoliated deciduous }\end{array}\end{array}$ & 0 & 1 & 3 \\
teeth & 2 & 0 & 0 \\
$\begin{array}{l}\text { Dental pulp of } \\
\text { deciduous/permanent }\end{array}$ & 14 & 29 & 1 \\
teeth & 16 & 19 & 2 \\
$\begin{array}{l}\text { Periodontal ligament } \\
\text { Multiple dental }\end{array}$ & 3 & 7 & 6 \\
source & & 5 & 6 \\
\hline
\end{tabular}

PDLSC and GMSC ( 3 in vivo, 3 in vitro). All these six studies confirmed that PDLSC showed better osteogenic potential compared to GMSC. Based on the included studies that compared osteogenic potential of multiple dental stem cells, PDLSC showed better osteogenic differentiation, followed by DPSC and SHED.

Almost all of the selected studies employed histology (in vivo) or ALP assay and histochemical staining (in vitro) to evaluate the outcomes. Among the 65 in vivo studies, only six studies reported no in vivo bone formation seen with dental stem cells (DFCS-2, DPSC-3, and PDLSC-1). The comparisons of in vivo osteogenic differentiation of different dental stem cells are shown in Table 6 . The total number of studies in each type of dental stem cell in this comparison is increased due to the five in vivo studies compared to the osteogenic behavior of different dental stem cells.

3.3. Quality Assessment of the Selected Literature. In general, most of the studies included some information related to the animals they used. However the majority of the literature lacked the quality based on ARRIVE guidelines. Only two studies reported a sample size calculation, four studies reported blinding in assessment of the outcomes, and 17/65 studies mentioned randomization in their articles. None of the sixty-five studies mentioned the 3Rs (replacement, reduction, and refinement) in their articles. However, one study mentioned that they followed the ARRIVE guidelines.

In 96 in vitro studies, only one study mentioned the power calculation to sample size. Blinding in evaluation was reported in one in vitro study. Sixteen selected in vitro studies gave information that they repeated their experiments or measurement more than once. Supplemental Tables i, ii, iii, and iv (in Supplementary Material available online at http://dx.doi.org/10.1155/2015/378368) summarize the quality of the in vitro and in vivo studies selected in this review.

\section{Discussion}

The purpose of this review was to summarize the role of dental-derived stem cells (dental MSCs) and their effects on the osteogenic differentiation potential and bone regeneration. Both in vivo and in vitro studies were included in this review. In total, 137 studies were qualitatively reviewed. No randomized controlled trials (RCTs) were found in in vivo studies. The in vitro studies were mainly experimental studies on the osteogenic differentiation or factors enhancing/decreasing the osteogenic potential of various dental stem cells. Dental MSCs used in these studies were derived from the dental pulp, apical papilla, dental papilla, gingiva, dental follicle, dental-neural crest, and periodontal ligament.

The literature stated that dental pulp stem cells were the first to be identified as having mesenchymal properties in the year 2000 by Gronthos and coworkers [33]. To date, four clinical studies were reported using dental stem cells for bone regeneration $[9,22,24]$. Due to the paucity of published clinical studies, we did not include clinical studies in this review. We strongly believe that an in-depth appraisal of the literature on preclinical in vivo and in vitro studies is a prerequisite to understanding the efficacy of a new therapeutic approach before its translation into human use. Dental stem cells such as DPSC, SHED, PDLSC, SCAP, and DFSC fulfill the requirements for mesenchymal stem cell as described by the International Society for cellular therapy [34], that is, adhering to plastic, multilineage differentiation potential, positive to stromal cell markers (CD73, CD90, CD105, STRO1, Nanog) and absence of hematopoietic markers (CD14, CD34, CD45).

4.1. SCAPs. The soft tissue covering the root apex of developing teeth serves as a source for SCAPs. All the studies reported in humans are a source for obtaining SCAPs for their experiments. The four in vivo studies conducted in rats and mice revealed ectopic bone-like tissue formation seen at 12 weeks. The in vitro study by Wang and colleagues [35] found an interesting observation, that insulin growth factor 1 (IGF-1) enhanced the osteogenic differentiation but weakened the odontogenic differentiation of SCAPs. Studies by $\mathrm{Wu}$ and coworkers [36] confirmed that basic-fibroblast growth factor $b$ FGF inhibited the osteogenic differentiation of SCAP.

4.2. DFSCs. Among the four in vivo studies conducted in rats/mice, two studies $[37,38]$ reported a lack of new bone formation by using DFSCs. However the in vitro study conducted by Tsuchiya et al. reported an osteogenic potential with DFSCs in an appropriate osteogenic induction medium. The two failed studies used porcine or rat as their stem cell source [37, 38]. The study done by Honda et al. [39] demonstrated bone formation similar to intramembranous ossification in rat critical sized calvarial defects. In vitro studies showed that BMP-9 and BMP-6 promoted osteogenesis of DFSCs. A later report [40] mentioned that $37^{\circ} \mathrm{C}$ to $40^{\circ} \mathrm{C}$ was optimal for osteogenesis and DFSCs lost its osteogenesis at $41^{\circ} \mathrm{C}$. 


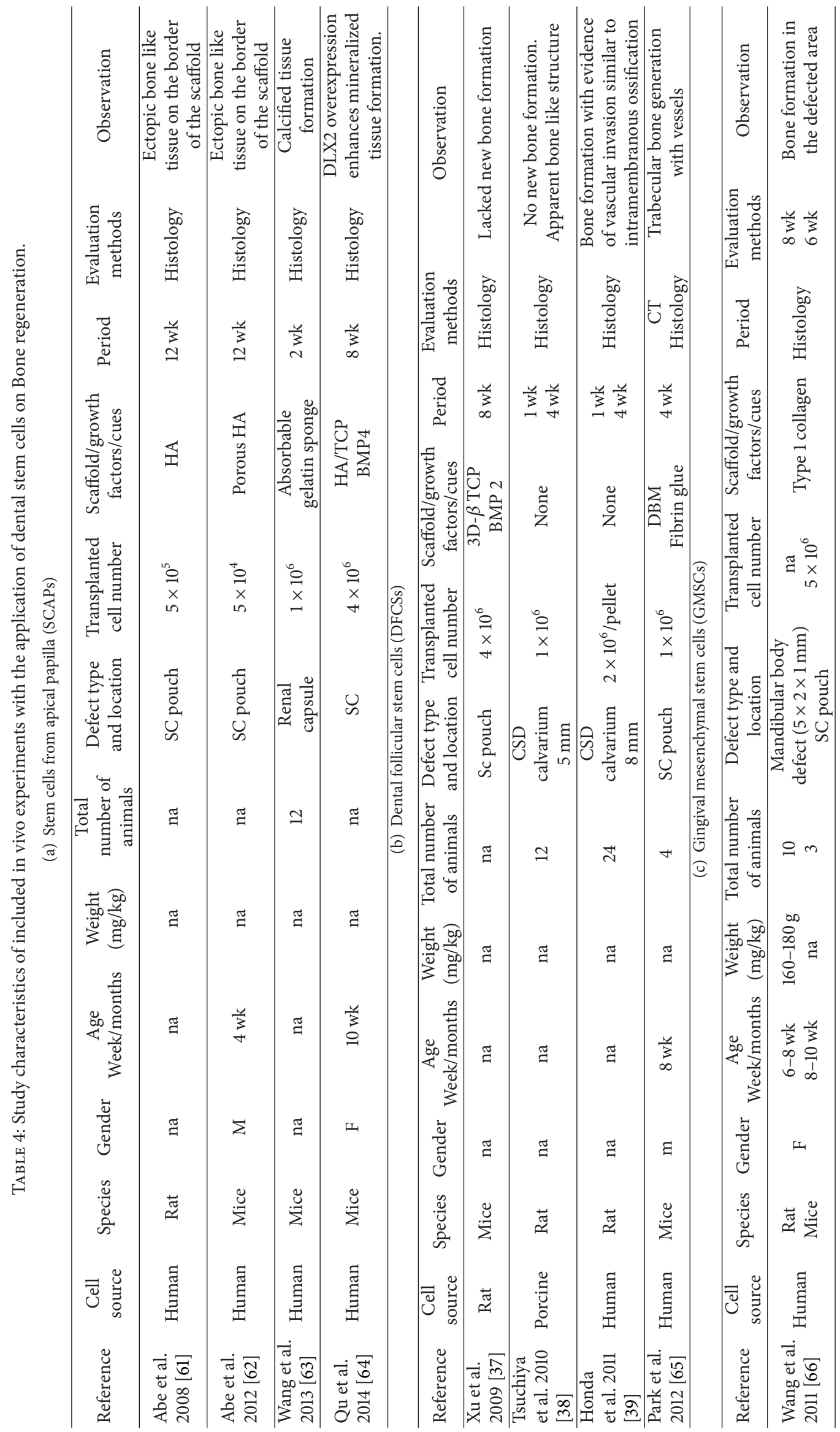




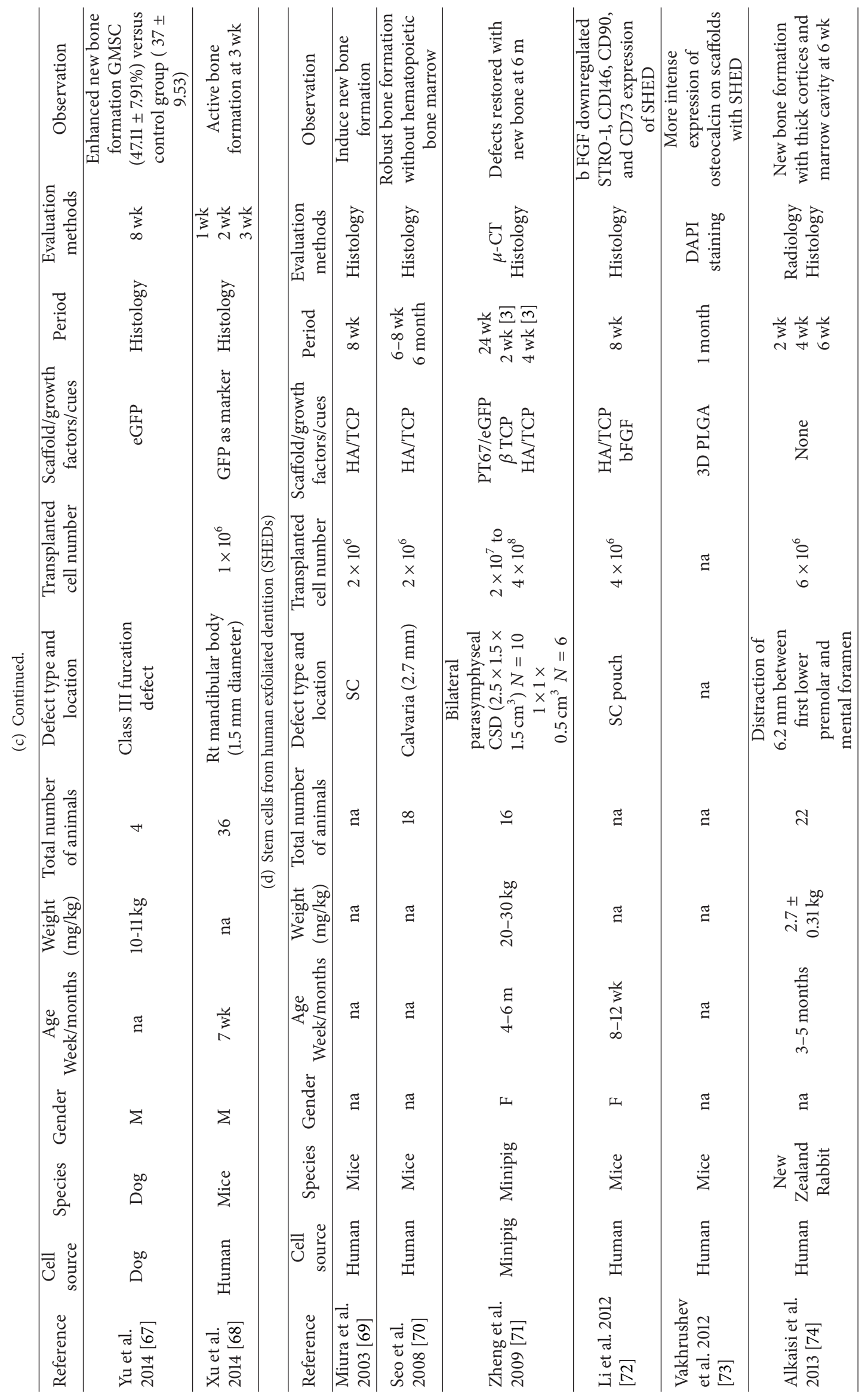




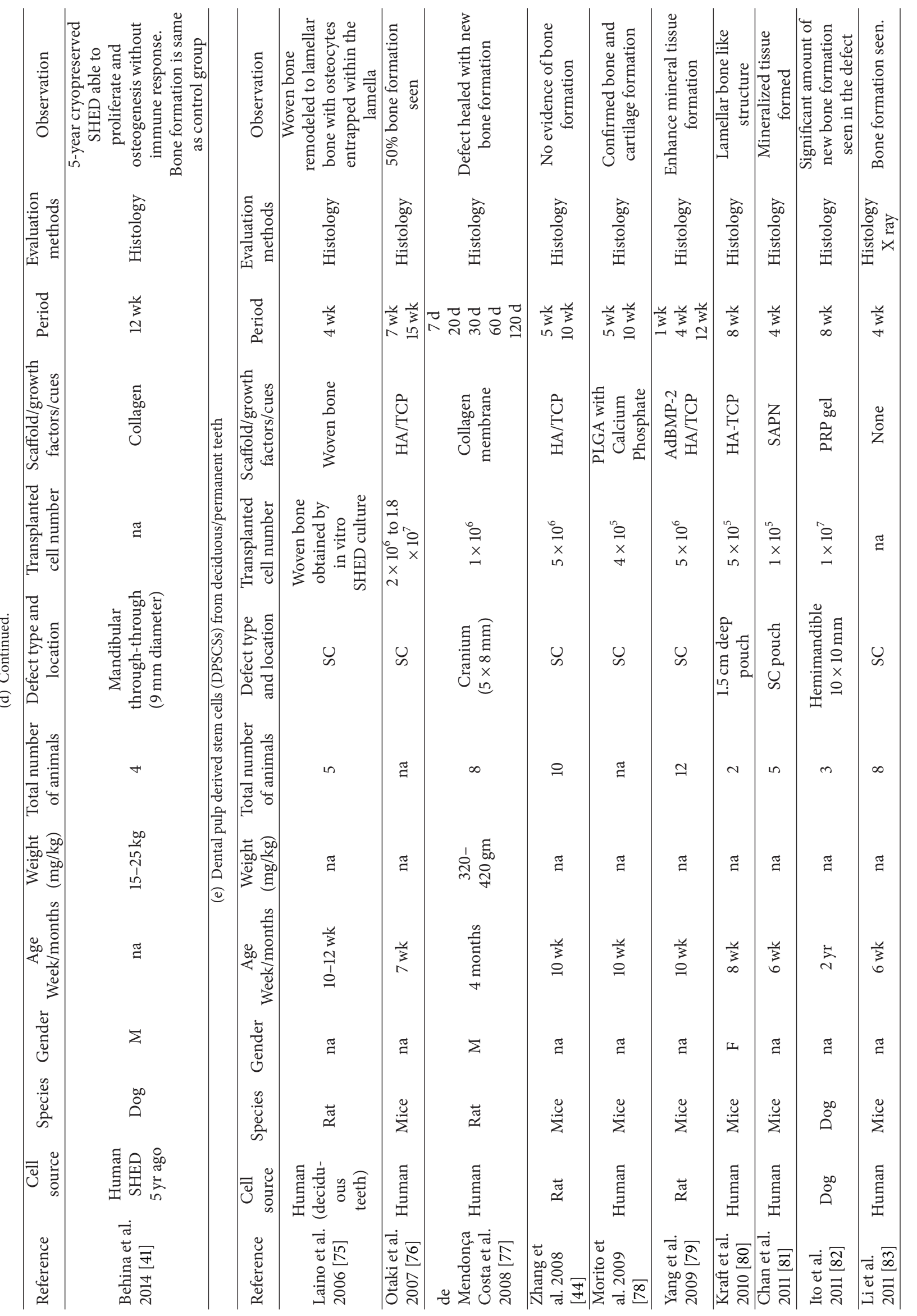




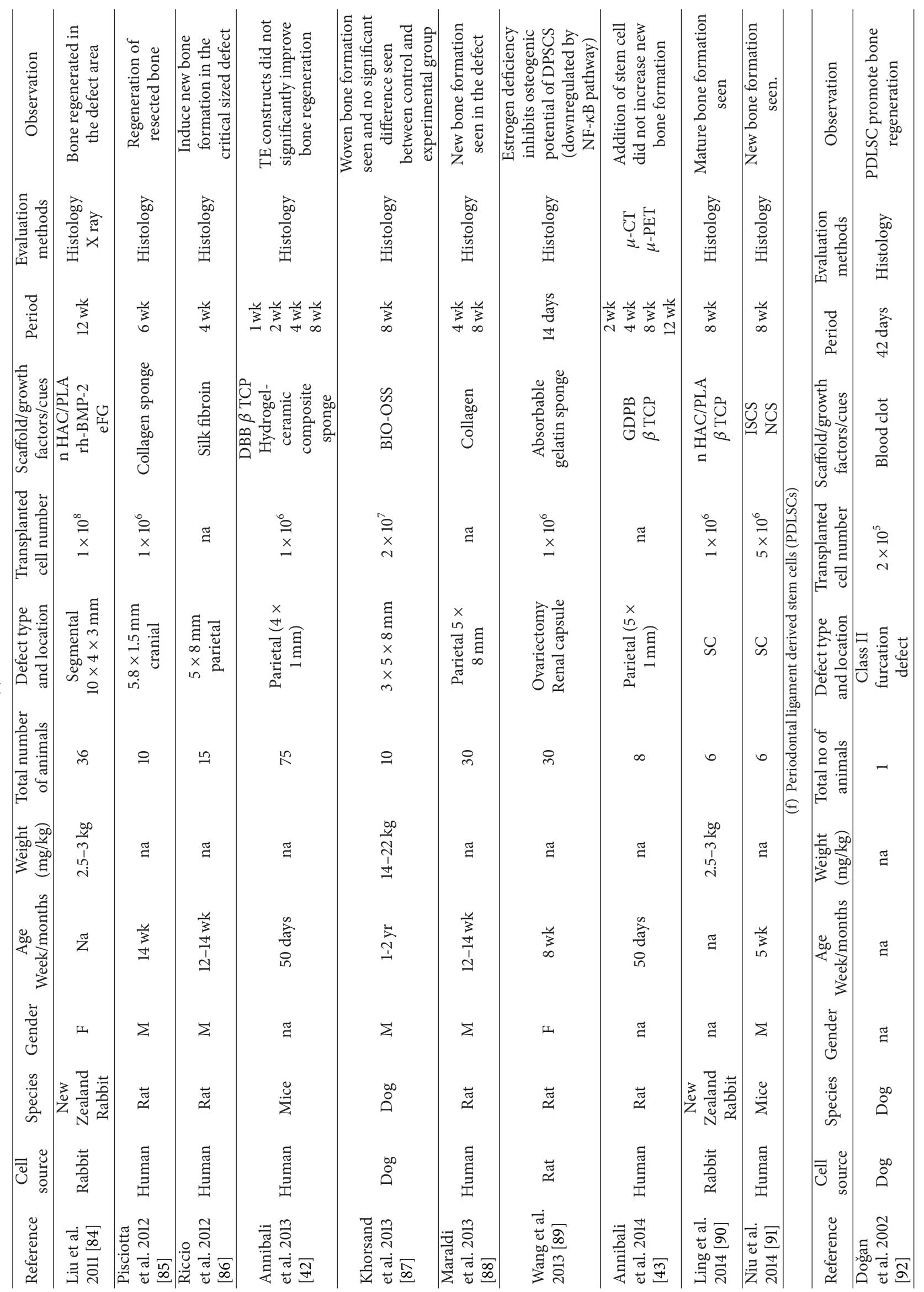




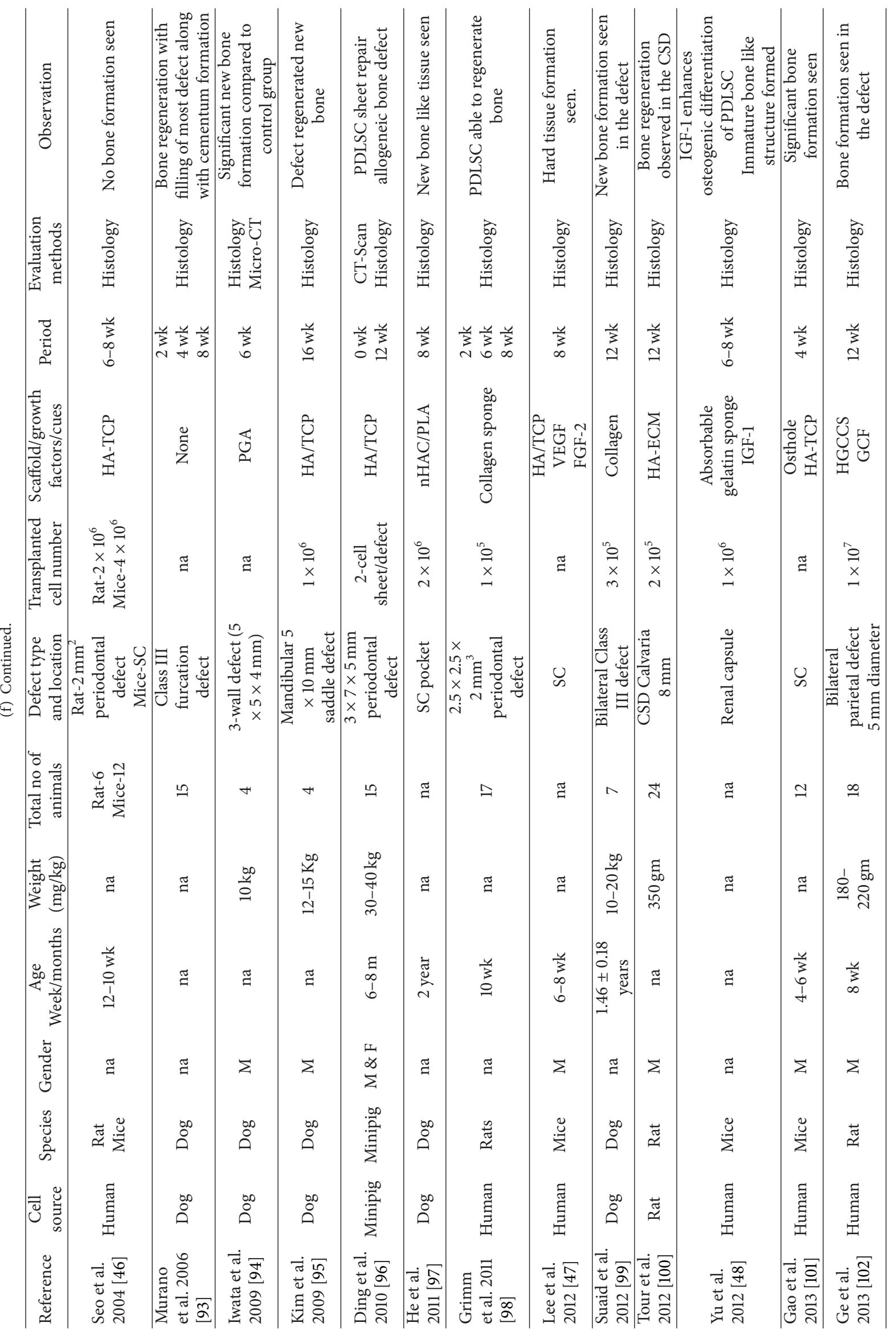




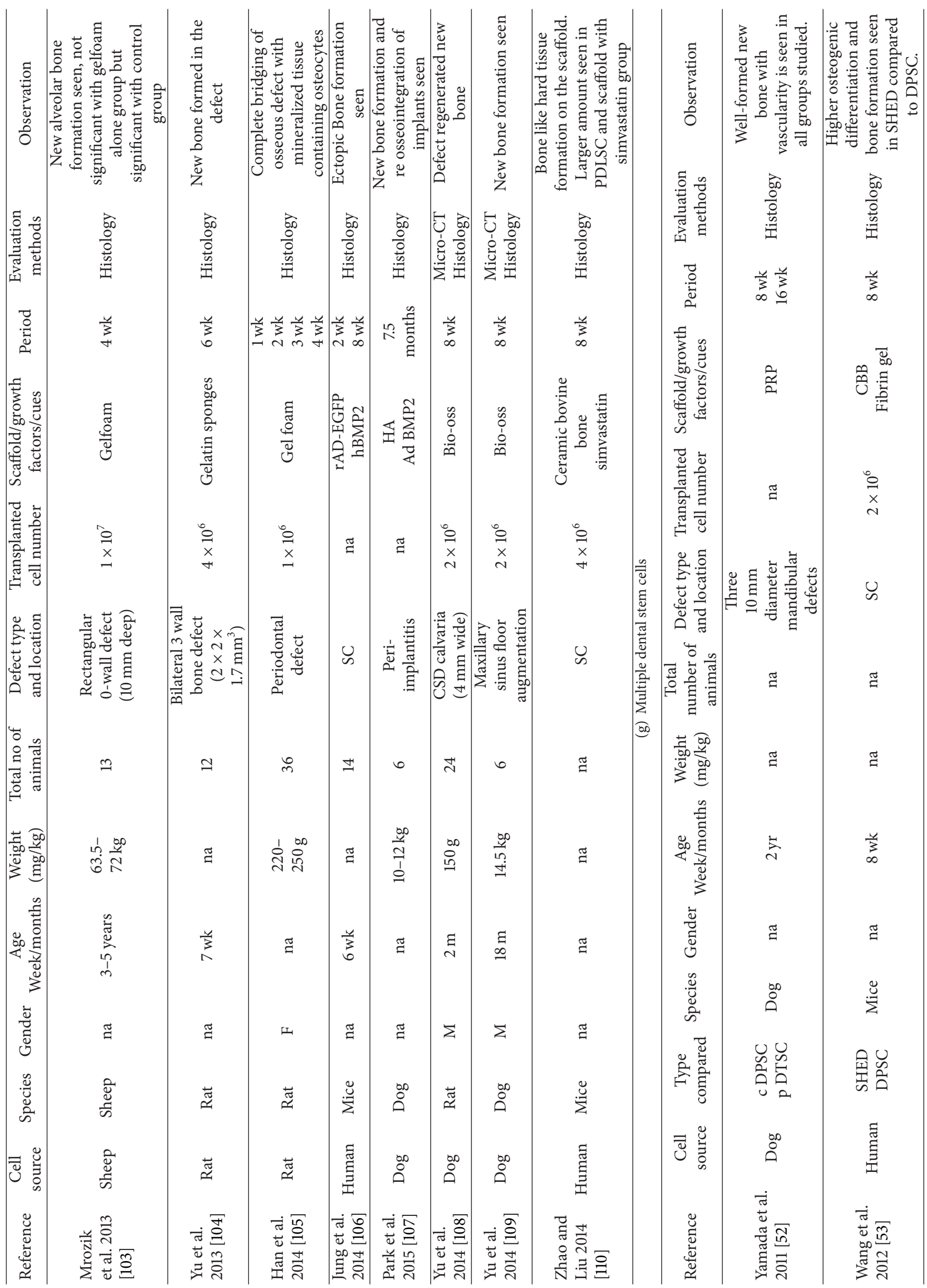




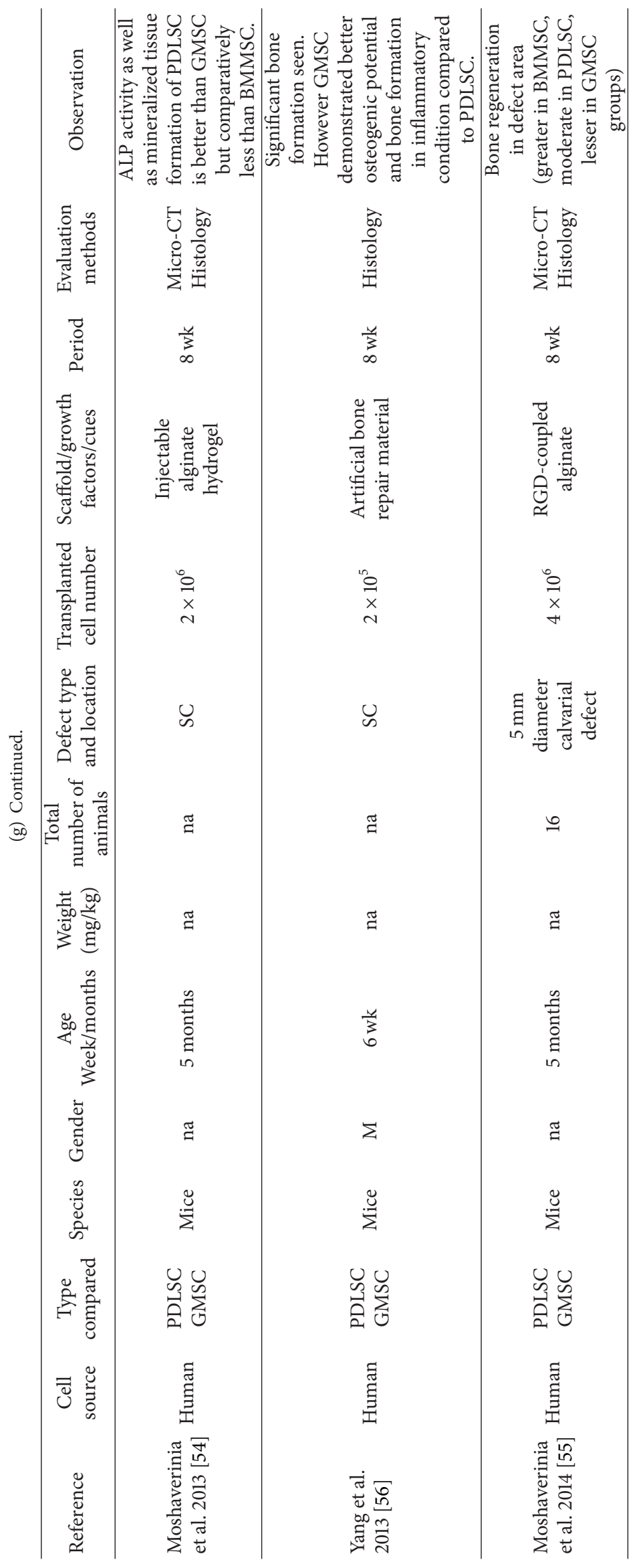


TABLE 5: Study characteristics of in vitro experiments with the application of dental stem cells on bone regeneration/osteogenesis potential.

(a) Stem cells from apical papilla (SCAPs)

\begin{tabular}{|c|c|c|c|c|c|}
\hline Reference & Cell source & Medium & Scaffold/carriers/cues/markers & $\begin{array}{c}\text { Evaluation } \\
\text { methods }\end{array}$ & Observation \\
\hline $\begin{array}{l}\text { Abe et al. } \\
2008[61]\end{array}$ & Human & OIM & HA & $\begin{array}{c}\text { ALP assay } \\
\text { Staining, SEM }\end{array}$ & $\begin{array}{l}\text { Time dependent ALP activity } \\
\text { seen. }\end{array}$ \\
\hline $\begin{array}{l}\text { Park et al. } \\
2009[111]\end{array}$ & Human & OIM & None & $\begin{array}{l}\text { Histochemical } \\
\text { staining }\end{array}$ & $\begin{array}{l}\text { Osteoblast differentiation and } \\
\text { mineralized nodule formation } \\
\text { seen. }\end{array}$ \\
\hline $\begin{array}{l}\text { Abe et al. } \\
2012[62]\end{array}$ & Human & OIM & None & $\begin{array}{l}\text { Histochemical } \\
\text { staining }\end{array}$ & $\begin{array}{l}\text { SCAPs differentiate into } \\
\text { osteoblasts, adipocytes, } \\
\text { chondrocytes, and smooth } \\
\text { muscle. }\end{array}$ \\
\hline $\begin{array}{l}\text { Wang et al. } \\
2012[35]\end{array}$ & Human & OIM & IGF-1 & $\begin{array}{l}\text { ALP assay } \\
\text { Histochemical } \\
\text { staining }\end{array}$ & $\begin{array}{l}\text { IGF-1 enhances osteogenic } \\
\text { differentiation but weakens } \\
\text { odontogenic differentiation of } \\
\text { SCAPs. }\end{array}$ \\
\hline $\begin{array}{l}\text { Wu et al. } 2012 \\
{[36]}\end{array}$ & Human & OIM & bFGF & $\begin{array}{l}\text { ALP assay } \\
\text { Histochemical } \\
\text { staining }\end{array}$ & $\begin{array}{l}\text { SCAP cultured with bFGF shows } \\
\text { decreased mineralized nodule } \\
\text { formation and ALP activity, but } \\
\text { if pretreated with bFGF } \\
\text { increased mineralized nodule } \\
\text { formation is seen. }\end{array}$ \\
\hline $\begin{array}{l}\text { Wang et al. } \\
2013[63]\end{array}$ & Human & OIM & None & $\begin{array}{c}\text { ALP assay } \\
\text { Histochemical } \\
\text { staining } \\
\end{array}$ & $\begin{array}{l}\text { High ALP activity and RUNX2 } \\
\text { upregulation seen. }\end{array}$ \\
\hline $\begin{array}{l}\text { Qu et al. } 2014 \\
{[64]}\end{array}$ & Human & OIM & None & $\begin{array}{l}\text { ALP assay } \\
\text { Histochemical } \\
\text { staining }\end{array}$ & $\begin{array}{l}\text { Significant mineralization } \\
\text { observed and enhanced } \\
\text { osteogenesis is linked to DLX2. }\end{array}$ \\
\hline
\end{tabular}

(b) Dental papilla stem cells

\begin{tabular}{lccccc}
\hline Reference & Cell source & Medium & Scaffold/carriers/cues/markers & $\begin{array}{c}\text { Evaluation } \\
\text { methods }\end{array}$ & Observation \\
\hline $\begin{array}{l}\text { Ikeda et al. } \\
2006[112]\end{array}$ & Human & OIM & HA & ALP assay & $\begin{array}{l}\text { In vitro osteogenic differentiation } \\
\text { observed if cultured in presence of OIM. }\end{array}$ \\
\hline
\end{tabular}

(c) Dental follicular stem cells (DFCSs)

\begin{tabular}{|c|c|c|c|c|c|}
\hline Reference & $\begin{array}{c}\text { Cell } \\
\text { source }\end{array}$ & Medium & Scaffold/carriers/cues/markers & $\begin{array}{l}\text { Evaluation } \\
\text { methods }\end{array}$ & Observation \\
\hline $\begin{array}{l}\text { Tsuchiya et al. } \\
2010[38]\end{array}$ & Porcine & OIM & None & $\begin{array}{l}\text { ALP assay } \\
\text { Histochemical } \\
\text { staining }\end{array}$ & DFCS has osteogenic potential. \\
\hline $\begin{array}{l}\text { Honda et al. } 2011 \\
\text { [39] }\end{array}$ & Human & GCM & None & $\begin{array}{l}\text { ALP assay } \\
\text { Histochemical } \\
\text { staining }\end{array}$ & $\begin{array}{l}3 \text { distinct cell populations were } \\
\text { identified with DFCS. Among the } \\
\text { three, two of them showed strong } \\
\text { calcium accumulation. }\end{array}$ \\
\hline $\begin{array}{l}\text { Viale-Bouroncle } \\
\text { et al. } 2011 \text { [113] }\end{array}$ & Human & OIM & $\begin{array}{l}\text { Polydimethylsiloxane } \\
\text { Fibronectin }\end{array}$ & ALP assay & $\begin{array}{l}\text { Soft surface improved the induction } \\
\text { of osteogenesis differentiation of } \\
\text { DFSC compared to higher stiffness. }\end{array}$ \\
\hline $\begin{array}{l}\text { Aonuma et al. } \\
2012[114]\end{array}$ & Human & OIM & None & $\begin{array}{l}\text { ALP assay } \\
\text { Histochemical } \\
\text { staining }\end{array}$ & ALP activity higher than hMSC. \\
\hline Li et al. 2012 [115] & Rat & OIM & $\begin{array}{l}\text { Ad-BMP9 } \\
\text { Ad-GFP }\end{array}$ & $\begin{array}{l}\text { Histological } \\
\text { staining }\end{array}$ & $\begin{array}{l}\text { BMP } 9 \text { enhances osteogenesis of } \\
\text { DFCS. }\end{array}$ \\
\hline $\begin{array}{l}\text { Park et al. } 2012 \\
{[65]}\end{array}$ & Human & OIM & None & $\begin{array}{l}\text { Histochemical } \\
\text { staining }\end{array}$ & $\begin{array}{l}\text { DFSC able to undergo osteogenic } \\
\text { differentiation. }\end{array}$ \\
\hline $\begin{array}{l}\text { Mori et al. } 2012 \\
{[116]}\end{array}$ & Human & OIM & None & $\begin{array}{l}\text { ALP assay } \\
\text { Histochemical } \\
\text { staining }\end{array}$ & $\begin{array}{l}\text { High level of ALP expression, } \\
\text { osteogenic potential, and } \\
\text { mineralized nodule formation seen. }\end{array}$ \\
\hline
\end{tabular}


(c) Continued

\begin{tabular}{lccccc}
\hline Reference & $\begin{array}{c}\text { Cell } \\
\text { source }\end{array}$ & Medium & Scaffold/carriers/cues/markers & $\begin{array}{c}\text { Evaluation } \\
\text { methods }\end{array}$ & Observation \\
\hline $\begin{array}{l}\text { Rezai Rad et al. } \\
2013[40]\end{array}$ & Rat & OIM & None & $\begin{array}{c}\text { ALP assay } \\
\text { Histochemical } \\
\text { staining }\end{array}$ & $\begin{array}{l}\text { Osteogenesis of DFSC increased } \\
\text { with temperature from } 37^{\circ} \mathrm{C} \text { to } 40^{\circ} \mathrm{C} \\
\text { but lost its potential at } 41^{\circ} \mathrm{C} .\end{array}$ \\
\hline $\begin{array}{l}\text { Takahashi et al. } \\
2013[117]\end{array}$ & Human & OIM & None & $\begin{array}{l}\text { DFSC can undergo osteogenic } \\
\text { differentiation in the absence of } \\
\text { dexamethasone and BMP } 6 \text { is the } \\
\text { key gene in osteogenic } \\
\text { differentiation of DFSC. }\end{array}$ \\
\hline $\begin{array}{l}\text { Yao et al. 2013 } \\
\text { [118] }\end{array}$ & Rat & OIM & ALP assay & $\begin{array}{l}\text { DFSC lost its osteogenesis during in } \\
\text { vitro expansion; addition of BMP-6 } \\
\text { dramatically enhances osteogenesis } \\
\text { of late passage. }\end{array}$ \\
\hline
\end{tabular}

(d) Gingival mesenchymal stem cells (GMSCs)

\begin{tabular}{lccccc}
\hline Reference & Cell source & Medium & Scaffold/carriers/cues/markers & $\begin{array}{c}\text { Evaluation } \\
\text { methods }\end{array}$ & Observation \\
\hline $\begin{array}{l}\text { Yu et al. 2014 } \\
{[67]}\end{array}$ & Human & OIM & None & $\begin{array}{c}\text { ALP assay } \\
\text { Histochemical } \\
\text { staining }\end{array}$ & $\begin{array}{l}\text { Mineralized nodule formed in the } \\
\text { experimental group. }\end{array}$ \\
\hline
\end{tabular}

(e) Dental neural crest stem cells

\begin{tabular}{|c|c|c|c|c|c|}
\hline Reference & Cell source & Medium & Scaffold/carriers/cues/markers & $\begin{array}{c}\text { Evaluation } \\
\text { methods }\end{array}$ & Observation \\
\hline $\begin{array}{l}\text { Degistirici } \\
\text { et al. } 2010 \\
{[119]}\end{array}$ & Human & OIM & None & $\begin{array}{l}\text { ALP assay } \\
\text { Histology }\end{array}$ & Bone like matrix formation seen. \\
\hline
\end{tabular}

(f) Stem cells from human exfoliated dentition (SHEDs)

\begin{tabular}{|c|c|c|c|c|c|}
\hline Reference & $\begin{array}{c}\text { Cell } \\
\text { source }\end{array}$ & Medium & Scaffold/carriers/cues/markers & $\begin{array}{l}\text { Evaluation } \\
\text { methods }\end{array}$ & Observation \\
\hline $\begin{array}{l}\text { Miura et al. } \\
2003[69]\end{array}$ & Human & OIM & rhBMP 4 & $\begin{array}{l}\text { Histochemical } \\
\text { staining }\end{array}$ & Osteogenic differentiation observed. \\
\hline $\begin{array}{l}\text { Vakhrushev } \\
\text { et al. } 2010[120]\end{array}$ & Human & $\begin{array}{l}\text { Serum- } \\
\text { free } \\
\text { OIM }\end{array}$ & 3D polylactide matrix & $\begin{array}{l}\text { Histochemical } \\
\text { staining }\end{array}$ & $\begin{array}{l}\text { SHED and BMMSC have similar } \\
\text { phenotype and identical osteogenic } \\
\text { potential. }\end{array}$ \\
\hline Li et al. 2012 [72] & Human & OIM & bFGF & $\begin{array}{l}\text { Histochemical } \\
\text { staining }\end{array}$ & bFGF inhibits osteogenic induction. \\
\hline $\begin{array}{l}\text { Viale-Bouroncle } \\
\text { et al. } 2012[121]\end{array}$ & Human & OIM & $\begin{array}{l}\text { PDMS } \\
\text { Fibronectin }\end{array}$ & $\begin{array}{l}\text { ALP assay } \\
\text { Histochemical } \\
\text { staining }\end{array}$ & $\begin{array}{l}\text { Rigid scaffold supports proliferation and } \\
\text { osteogenesis of SHED. }\end{array}$ \\
\hline $\begin{array}{l}\text { Vakhrushev } \\
\text { et al. } 2013 \text { [122] }\end{array}$ & Human & $\begin{array}{l}\text { Serum- } \\
\text { free } \\
\text { OIM }\end{array}$ & TCP & $\begin{array}{l}\text { Histochemical } \\
\text { staining }\end{array}$ & $\begin{array}{l}\text { TCP increases osteogenic differentiation, } \\
\text { ossification foci and enhances ECM } \\
\text { production by SHED. }\end{array}$ \\
\hline $\begin{array}{l}\text { Karadzic et al. } \\
2014[123]\end{array}$ & Human & OIM & $\begin{array}{l}\text { 3D HAP, PLGA, alginate, } \\
\text { EVA/EVV }\end{array}$ & $\begin{array}{l}\text { ALP assay } \\
\text { Histology }\end{array}$ & $\begin{array}{l}\text { All four are suitable carrier for SHED. } \\
\text { Low level of osteoblastic differentiation is } \\
\text { demonstrated in EVA/EVV. }\end{array}$ \\
\hline $\begin{array}{l}\text { Yu et al. } 2014 \\
{[124]}\end{array}$ & Human & OIM & None & $\begin{array}{l}\text { ALP assay } \\
\text { Histochemical } \\
\text { staining }\end{array}$ & $\begin{array}{l}\text { ALP activity and in vitro mineralization } \\
\text { were not different between SCID and } \\
\text { SHED. However more TNF- } \alpha \text { is seen } \\
\text { with SCID. }\end{array}$ \\
\hline
\end{tabular}

(g) Dental pulp derived stem cells (DPSCSs) from deciduous/permanent teeth

\begin{tabular}{lccccc}
\hline Reference & Cell source & Medium & Scaffold/carriers/cues/markers & $\begin{array}{c}\text { Evaluation } \\
\text { methods }\end{array}$ & Observation \\
\hline $\begin{array}{l}\text { Gronthos et } \\
\text { al. 2000[33] }\end{array}$ & Human & OIM & None & ALP assay $\begin{array}{l}\text { DPSC shows osteogenic potential } \\
\text { (formed condensed nodule with high } \\
\text { level of calcium) and forms more CFU } \\
\text { than BMMSC. }\end{array}$ \\
\hline
\end{tabular}


(g) Continued.

\begin{tabular}{|c|c|c|c|c|c|}
\hline Reference & Cell source & Medium & Scaffold/carriers/cues/markers & $\begin{array}{l}\text { Evaluation } \\
\text { methods }\end{array}$ & Observation \\
\hline $\begin{array}{l}\text { Laino et al. } \\
2005[45]\end{array}$ & Human & OIM & None & $\begin{array}{l}\text { ALP assay } \\
\text { Histochemical } \\
\text { staining } \\
\end{array}$ & $\begin{array}{l}\text { DPSC able to generate living autologous } \\
\text { fibrous bone tissue (LAB). }\end{array}$ \\
\hline $\begin{array}{l}\text { Laino et al. } \\
2006 \text { [75] }\end{array}$ & Human & OIM & None & $\begin{array}{l}\text { Calcium } \\
\text { staining }\end{array}$ & $\begin{array}{l}\text { Demonstrated pluripotency. Able to } \\
\text { differentiate into osteoblast. }\end{array}$ \\
\hline $\begin{array}{l}\text { d'Aquino et } \\
\text { al. } 2007 \text { [125] }\end{array}$ & Human & OIM & None & $\begin{array}{l}\text { ALP assay } \\
\text { Histochemical } \\
\text { staining }\end{array}$ & DPSC able to form woven bone in vitro. \\
\hline $\begin{array}{l}\text { Cheng et al. } \\
2008 \text { [126] }\end{array}$ & Chimpanzee & OIM & None & $\begin{array}{l}\text { Histochemical } \\
\text { staining }\end{array}$ & $\begin{array}{l}\text { Osteogenic capacity of cDPSC was } \\
\text { comparable to human BMMSC, DPSC, } \\
\text { and rBMSC. }\end{array}$ \\
\hline $\begin{array}{l}\text { Graziano } \\
\text { et al. } 2008 \\
{[127]}\end{array}$ & Human & $\begin{array}{l}\text { OIM } \\
\text { Rotating } \\
\text { culture }\end{array}$ & HA, Ti, PLGA & $\begin{array}{l}\text { ALP assay } \\
\text { Histochemical } \\
\text { staining }\end{array}$ & $\begin{array}{l}\text { PLGA shows better scaffold suitability } \\
\text { for DPSC ( } 1 \mathrm{~mm} \text { bone tissue on PLGA, } \\
0.3 \mathrm{~mm} \text { in } \mathrm{Ti} \text {, and no bone tissue } \\
\text { formation seen in titanium covered with } \\
\mathrm{HA}) \text {. }\end{array}$ \\
\hline $\begin{array}{l}\text { Morito et al. } \\
2009[78]\end{array}$ & Human & OIM & $\begin{array}{l}\text { PLGA } \\
\text { bFGF }\end{array}$ & $\begin{array}{l}\text { ALP assay } \\
\text { Histochemical } \\
\text { staining } \\
\end{array}$ & $\begin{array}{l}\text { Membrane bone like tissue formed } \\
\text { around PLGA. }\end{array}$ \\
\hline $\begin{array}{l}\text { Alge et al. } \\
2010[128]\end{array}$ & Rat & OIM & None & $\begin{array}{l}\text { ALP assay } \\
\text { Histochemical } \\
\text { staining }\end{array}$ & $\begin{array}{l}\text { Significantly higher ALP activity than } \\
\text { control group. }\end{array}$ \\
\hline $\begin{array}{l}\text { Han et al. } \\
2010[129]\end{array}$ & Human & $\begin{array}{c}\text { OIM } \\
\text { Mechanical } \\
\text { bioreactor }\end{array}$ & None & $\begin{array}{l}\text { ALP assay } \\
\text { Histochemical } \\
\text { staining }\end{array}$ & $\begin{array}{l}\text { Mechanical stimulation promotes } \\
\text { osteogenic differentiation and } \\
\text { osteogenesis of DPSC. }\end{array}$ \\
\hline $\begin{array}{l}\text { Mangano } \\
\text { et al. } 2010 \\
{[130]} \\
\end{array}$ & Human & OIM & LST Ti & $\begin{array}{l}\text { Histology } \\
\text { SEM }\end{array}$ & $\begin{array}{l}\text { More osteoblast and bone formation } \\
\text { seen with laser treated titanium surface. }\end{array}$ \\
\hline $\begin{array}{l}\text { Mori et al. } \\
2010[131]\end{array}$ & Human & OIM & None & ALP assay & $\begin{array}{l}\text { DPSC formed mineralized matrix } \\
\text { nodules showing osteoblast features. }\end{array}$ \\
\hline $\begin{array}{l}\text { Spath et al. } \\
2010[132]\end{array}$ & Human & OIM & $\begin{array}{l}\text { Lenti virus vector expressing } \beta \\
\text { galactoside }\end{array}$ & $\begin{array}{l}\text { ALP assay } \\
\text { Histochemical } \\
\text { staining } \\
\end{array}$ & $\begin{array}{l}\text { DPSC by explant culture method } \\
\text { exhibits elevated proliferation and } \\
\text { osteogenic potential. }\end{array}$ \\
\hline $\begin{array}{l}\text { Chan et al. } \\
2011[81]\end{array}$ & Human & OIM & SAPN & $\begin{array}{l}\text { Histochemical } \\
\text { staining }\end{array}$ & $\begin{array}{l}\text { DPSC survives encapsulation by SAPN } \\
\text { and calcium salt deposition seen. }\end{array}$ \\
\hline $\begin{array}{l}\text { Galli et al. } \\
2011[133]\end{array}$ & Human & OIM & 3DTi & $\begin{array}{l}\text { ALP assay } \\
\text { Histochemical } \\
\text { staining }\end{array}$ & $\begin{array}{l}\text { Increased expression of ALP genes and } \\
\text { BMP } 2 \text { genes and increased osteogenic } \\
\text { differentiation. }\end{array}$ \\
\hline $\begin{array}{l}\text { D'Alimonte et } \\
\text { al. } 2011[134]\end{array}$ & Human & OIM & VEGF-A165 peptide & $\begin{array}{l}\text { ALP assay } \\
\text { Histochemical } \\
\text { staining } \\
\end{array}$ & $\begin{array}{l}\text { VEGF enhances differentiation of DPSC } \\
\text { towards osteoblast and DPSC showed } \\
\text { negative hematopoietic marker. }\end{array}$ \\
\hline $\begin{array}{l}\text { Li et al. } 2011 \\
{[83]}\end{array}$ & Human & OIM & $3 \mathrm{D}$ gelatin & $\begin{array}{l}\text { ALP assay } \\
\text { Histochemical } \\
\text { staining } \\
\end{array}$ & $\begin{array}{l}\text { Increased ALP activity and osteoblast } \\
\text { compared to control group. }\end{array}$ \\
\hline $\begin{array}{l}\text { Mangano } \\
\text { et al. } 2011 \\
{[135]} \\
\end{array}$ & Human & OIM & Biocoral & $\begin{array}{l}\text { Histology } \\
\text { SEM }\end{array}$ & $\begin{array}{l}\text { Diffuse bone formation seen in the } \\
\text { scaffold. }\end{array}$ \\
\hline $\begin{array}{l}\text { Struys et al. } \\
2011[136]\end{array}$ & Human & OIM & None & $\begin{array}{c}\text { TEM } \\
\text { Staining } \\
\text { Image analysis }\end{array}$ & $\begin{array}{l}\text { Presence of multiple mineralization } \\
\text { nuclei. }\end{array}$ \\
\hline $\begin{array}{l}\text { Huang et al. } \\
2012[137]\end{array}$ & Rat & OIM & Flavanoid & $\begin{array}{l}\text { ALP assay } \\
\text { Histochemical } \\
\text { staining }\end{array}$ & $\begin{array}{l}\text { Flavonoid increases DPSCs ALP activity } \\
\text { by } 1.47 \text {-fold and upregulation of } \\
\text { RUNX2by } 2.5 \text {-fold. }\end{array}$ \\
\hline $\begin{array}{l}\text { Huang et al. } \\
2012[138]\end{array}$ & Rat & OIM & MAO Ti & ALP assay & $\begin{array}{l}\text { Osteogenic potential of DPSC similar to } \\
\text { BMMSC. }\end{array}$ \\
\hline
\end{tabular}


(g) Continued.

\begin{tabular}{|c|c|c|c|c|c|}
\hline Reference & Cell source & Medium & Scaffold/carriers/cues/markers & $\begin{array}{l}\text { Evaluation } \\
\text { methods }\end{array}$ & Observation \\
\hline $\begin{array}{l}\text { Khann-Jain } \\
\text { et al. } 2012 \\
{[139]}\end{array}$ & Human & $\begin{array}{l}\text { Human } \\
\text { serum } \\
\text { (serum-free } \\
\text { OIM) }\end{array}$ & $\beta \mathrm{TCP}$ & $\begin{array}{l}\text { ALP assay } \\
\text { Histochemical } \\
\text { staining }\end{array}$ & $\begin{array}{l}\text { Matrix mineralization seen. Human } \\
\text { serum can be substituted for FBS which } \\
\text { facilitates translating from in vitro to } \\
\text { clinical trials. }\end{array}$ \\
\hline $\begin{array}{l}\text { Pisciotta et al. } \\
2012[85]\end{array}$ & Human & $\begin{array}{l}\text { Human } \\
\text { serum } \\
\text { OIM }\end{array}$ & Collagen sponge & $\begin{array}{l}\text { ALP assay } \\
\text { Histochemical } \\
\text { staining }\end{array}$ & $\begin{array}{l}\text { High proliferation rate and osteogenic } \\
\text { differentiation of DPSC in human } \\
\text { serum compared to FCS. }\end{array}$ \\
\hline $\begin{array}{l}\text { Taşli et al. } \\
2014[140]\end{array}$ & Human & OIM & $\begin{array}{l}\text { BMP2,7 } \\
\text { Plasmids, GFP }\end{array}$ & $\begin{array}{c}\text { ALP assay } \\
\text { Histochemical } \\
\text { staining }\end{array}$ & $\begin{array}{l}\text { Transfection of human tooth germ cells } \\
\text { with BMP2,7, induced osteogenic, and } \\
\text { odontogenic differentiation. }\end{array}$ \\
\hline $\begin{array}{l}\text { Palumbo } \\
\text { et al. } 2013 \\
{[141]}\end{array}$ & Human & OIM & $\begin{array}{l}\text { 3D scaffold matrigel } \\
\text { Titanium }\end{array}$ & $\begin{array}{l}\text { SEM } \\
\text { Confocal } \\
\text { TEM } \\
\end{array}$ & $\begin{array}{l}\text { Human osteoblasts from bone biopsies } \\
\text { are appropriate compared to DPSCs. }\end{array}$ \\
\hline $\begin{array}{l}\text { Zavatti et al. } \\
2013 \text { [142] }\end{array}$ & Human & $\begin{array}{l}\text { Ferutinin } \\
\text { OIM }\end{array}$ & None & Staining & $\begin{array}{l}\text { Ferutinin enhances osteoblastic } \\
\text { differentiation of DPSC. }\end{array}$ \\
\hline $\begin{array}{l}\text { Akkouch } \\
\text { et al. } 2014 \\
{[143]}\end{array}$ & Human & OIM & 3D Col/HA/PLCL & $\begin{array}{c}\text { Micro-CT } \\
\text { ALP assay } \\
\text { Histochemical } \\
\text { staining } \\
\end{array}$ & $\begin{array}{l}30 \% \text { increase in bone nodule formation } \\
\text { and tissue mineralization seen on } \\
\text { surface as well inside the scaffold. }\end{array}$ \\
\hline $\begin{array}{l}\text { Amir et al. } \\
2014[144]\end{array}$ & $\begin{array}{c}\text { Macaque } \\
\text { Nemestrima }\end{array}$ & $\begin{array}{l}\text { Chitosan } \\
\text { OIM }\end{array}$ & None & $\begin{array}{c}\text { ALP assay } \\
\text { Histochemical } \\
\text { staining } \\
\end{array}$ & $\begin{array}{l}\text { Chitosan stimulates proliferation and } \\
\text { early osteogenic differentiation of DPSC } \\
\text { compared to dexamethasone. }\end{array}$ \\
\hline $\begin{array}{l}\text { Guo et al. } \\
2014[145]\end{array}$ & Human & OIM & $\begin{array}{l}\text { Fluorapatite } \\
\text { PCL }\end{array}$ & $\begin{array}{c}\text { ALP assay } \\
\text { Histochemical } \\
\text { staining } \\
\end{array}$ & $\begin{array}{l}\text { Scaffolds provided favorable ECM } \\
\text { microenvironment for proliferation and } \\
\text { osteogenic differentiation. }\end{array}$ \\
\hline $\begin{array}{l}\text { Huang et al. } \\
2014[146]\end{array}$ & Human & OIM & $\begin{array}{c}\text { Lenti virus } \\
\text { Cloned human OCT4, Nanog }\end{array}$ & $\begin{array}{c}\text { ALP assay } \\
\text { Histochemical } \\
\text { staining }\end{array}$ & $\begin{array}{l}\text { OCT } 4 \text { and Nanog act as a major } \\
\text { regulator in maintaining mesenchymal } \\
\text { properties in DPSC. }\end{array}$ \\
\hline $\begin{array}{l}\text { Jensen et al. } \\
2014 \text { [147] }\end{array}$ & Human & OIM & $\begin{array}{l}\text { NSP-PCL } \\
\text { HT-PCL }\end{array}$ & $\begin{array}{c}\text { ALP assay } \\
\text { Histochemical } \\
\text { staining }\end{array}$ & $\begin{array}{l}\text { Both scaffolds promote calcium } \\
\text { deposition, but HT-PCL supports only } \\
\text { cell proliferation and migration. }\end{array}$ \\
\hline $\begin{array}{l}\text { Ji et al. } 2014 \\
{[148]}\end{array}$ & Human & $\begin{array}{c}\text { OIM } \\
\text { Biomimetic } \\
\text { bioreactor }\end{array}$ & 3D agarose gel & $\begin{array}{c}\text { ALP assay } \\
\text { Histochemical } \\
\text { staining } \\
\end{array}$ & $\begin{array}{l}\text { Mechanical loading enhances } \\
\text { osteogenesis and bone formation }\end{array}$ \\
\hline $\begin{array}{l}\text { Kanafi et al. } \\
2014[149]\end{array}$ & Human & OIM & Alginate hydrogel & $\begin{array}{c}\text { Calcium } \\
\text { quantification } \\
\text { assay } \\
\text { Staining } \\
\end{array}$ & $\begin{array}{l}\text { DPSC immobilized in alginate hydrogel } \\
\text { exhibits enhanced osteogenic potential }\end{array}$ \\
\hline $\begin{array}{l}\text { Niu et al. } \\
2014[91]\end{array}$ & Human & $\begin{array}{l}\text { OIM } \\
\text { cocultured } \\
\text { with silicic } \\
\quad \text { acid }\end{array}$ & Collagen & $\begin{array}{l}\text { ALP assay } \\
\text { Histochemical } \\
\text { staining }\end{array}$ & $\begin{array}{l}\text { ISCS promotes proliferation, osteogenic } \\
\text { differentiation, and mineralization } \\
\text { compared with NCS. }\end{array}$ \\
\hline $\begin{array}{l}\text { Taşli et al. } \\
2013[150]\end{array}$ & Human & OIM & $\mathrm{NaB}$ & $\begin{array}{l}\text { ALP assay } \\
\text { Histochemical } \\
\text { staining }\end{array}$ & $\begin{array}{l}\text { NaB significantly increases level of ALP } \\
\text { activity and mineralization with higher } \\
\text { expression of osteogenic and } \\
\text { odontogenic genes. }\end{array}$ \\
\hline $\begin{array}{l}\text { Woloszyk } \\
\text { et al. } 2014 \\
{[151]}\end{array}$ & Human & $\begin{array}{l}\text { OIM } \\
\text { Spinner flask } \\
\text { bioreactor }\end{array}$ & Silk fibroin & $\begin{array}{l}\text { Micro-CT } \\
\text { Histology } \\
\text { ALP assay }\end{array}$ & $\begin{array}{l}\text { DPSCs have the potential to form } \\
\text { mineralized matrix when grown on 3D } \\
\text { scaffold enhanced by mechanical } \\
\text { loading. }\end{array}$ \\
\hline
\end{tabular}

(h) Periodontal ligament derived stem cells (PDLSCs)

\begin{tabular}{lccccc}
\hline Reference & $\begin{array}{c}\text { Cell } \\
\text { source }\end{array}$ & Medium & Scaffold/carriers/cues/markers & $\begin{array}{c}\text { Evaluation } \\
\text { methods }\end{array}$ & Observation \\
\hline $\begin{array}{l}\text { Gay et al. 2007 } \\
{[152]}\end{array}$ & Human & OIM & None & $\begin{array}{c}\text { Histochemical } \\
\text { staining }\end{array}$ & $\begin{array}{l}\text { PDLSC has osteogenic differentiation } \\
\text { and mineralization potential. }\end{array}$ \\
\hline
\end{tabular}


(h) Continued.

\begin{tabular}{|c|c|c|c|c|c|}
\hline Reference & $\begin{array}{l}\text { Cell } \\
\text { source }\end{array}$ & Medium & Scaffold/carriers/cues/markers & $\begin{array}{l}\text { Evaluation } \\
\text { methods }\end{array}$ & Observation \\
\hline $\begin{array}{l}\text { Trubiani et al. } 2007 \\
\text { [153] }\end{array}$ & Human & OIM & Xenogenic Porcine substitute & $\begin{array}{l}\text { ALP assay } \\
\text { Histochemical } \\
\text { staining }\end{array}$ & $\begin{array}{l}\text { Scaffold able to support PDLSC and } \\
\text { demonstrated osteogenic potential. }\end{array}$ \\
\hline $\begin{array}{l}\text { Zhou et al. } 2008 \\
{[154]}\end{array}$ & Human & OIM & None & $\begin{array}{l}\text { ALP assay } \\
\text { Histochemical } \\
\text { staining }\end{array}$ & $\begin{array}{l}\text { Time dependent increase in matrix } \\
\text { calcification observed with PDLSC. }\end{array}$ \\
\hline $\begin{array}{l}\text { Orciani et al. } 2009 \\
{[155]}\end{array}$ & Human & OIM & None & $\begin{array}{c}\text { TEM } \\
\text { SEM } \\
\text { ALP assay }\end{array}$ & $\begin{array}{l}\text { NO involved in osteogenesis of } \\
\text { PDLSC. In vitro osteogenesis of } \\
\text { PDLSC resulted in osteoblast like } \\
\text { cells with calcium deposits. }\end{array}$ \\
\hline He et al. 2011 [97] & Dog & OIM & Porous n HAC/PLA & ALP assay & $\begin{array}{l}\text { Osteogenic differentiation seen on } \\
\text { the scaffolds. }\end{array}$ \\
\hline $\begin{array}{l}\text { Silvério et al. } 2010 \\
\text { [51] }\end{array}$ & Human & OIM & None & $\begin{array}{l}\text { Histochemical } \\
\text { staining }\end{array}$ & $\begin{array}{l}\text { Deciduous periodontal ligament } \\
\text { derived cells promoted } 100 \% \text { mineral } \\
\text { nodule formation, while permanent } \\
\text { showed } 60 \% \text {. }\end{array}$ \\
\hline $\begin{array}{l}\text { Zhang et al. } 2011 \\
{[156]}\end{array}$ & Rats & OIM & None & $\begin{array}{l}\text { Histochemical } \\
\text { staining }\end{array}$ & $\begin{array}{l}\text { Decreased osteogenic differentiation } \\
\text { seen in PDLSC derived from } \\
\text { ovariectomised rats. }\end{array}$ \\
\hline $\begin{array}{l}\text { Zhou et al. } 2011 \\
\text { [49] }\end{array}$ & Human & OIM & Ibandronate & qRT-PCR & $\begin{array}{l}\text { Ibandronate promoted osteoblastic } \\
\text { differentiation of PDLSC. }\end{array}$ \\
\hline Ge et al. 2012 [157] & Human & OIM & IHGCCS & $\begin{array}{l}\text { ALP assay } \\
\text { Histochemical } \\
\text { staining }\end{array}$ & HGCS showed higher ALP activity. \\
\hline Lee et al. 2012 [47] & Human & OIM & $\begin{array}{l}\text { VEGF2 } \\
\text { FGF2 }\end{array}$ & $\begin{array}{l}\text { ALP assay } \\
\text { Histochemical } \\
\text { staining }\end{array}$ & $\begin{array}{l}\text { VEGF has positive effect on } \\
\text { osteogenic differentiation. FGF has } \\
\text { positive effect on proliferation rate. }\end{array}$ \\
\hline $\begin{array}{l}\text { Sununliganon and } \\
\text { Singhatanadgit } \\
2012[158]\end{array}$ & Human & OIM & None & Staining & $\begin{array}{l}\text { PDLSC able to form mineralized } \\
\text { mass. }\end{array}$ \\
\hline Yu et al. 2012 [48] & Human & OIM & IGF-1 & $\begin{array}{l}\text { ALP assay } \\
\text { Histochemical } \\
\text { staining } \\
\end{array}$ & $\begin{array}{l}\text { IGF-1 stimulates osteogenic potential } \\
\text { of PDLSC. }\end{array}$ \\
\hline $\begin{array}{l}\text { Zhang et al. } 2012 \\
{[50]}\end{array}$ & Human & $\begin{array}{l}\text { OIM } \\
\text { LMHF }\end{array}$ & None & $\begin{array}{l}\text { ALP assay } \\
\text { Histochemical } \\
\text { staining }\end{array}$ & $\begin{array}{l}\text { LMHF promoted osteogenic } \\
\text { potential of PDLSC. }\end{array}$ \\
\hline Gao et al. 2013 [101] & Human & OIM & None & $\begin{array}{l}\text { ALP assay } \\
\text { Histochemical } \\
\text { staining }\end{array}$ & $\begin{array}{l}\text { PDLSC able to form mineralized } \\
\text { nodule. }\end{array}$ \\
\hline Ge et al. 2013 [102] & Human & OIM & $\begin{array}{l}\text { HAp } \\
\text { PADM }\end{array}$ & $\begin{array}{l}\text { ALP assay } \\
\text { Histochemical } \\
\text { staining }\end{array}$ & $\begin{array}{l}\text { Higher ALP activity and osteogenic } \\
\text { differentiation seen in Hap-PADM } \\
\text { than pure PADM. }\end{array}$ \\
\hline $\begin{array}{l}\text { Houshmand et al. } \\
2013 \text { [159] }\end{array}$ & Human & OIM & EMD & $\begin{array}{l}\text { Histochemical } \\
\text { staining }\end{array}$ & $\begin{array}{l}\text { EMD has no effect on osteoblastic } \\
\text { differentiation of BMMSC or PDLSC. }\end{array}$ \\
\hline $\begin{array}{l}\text { Kato et al. } 2013 \\
{[160]}\end{array}$ & Human & OIM & Synthetic peptide & ALP assay & $\begin{array}{l}\text { More number of calcified nodules } \\
\text { seen in culture with synthetic } \\
\text { peptide. }\end{array}$ \\
\hline $\begin{array}{l}\text { Kim et al. } 2013 \\
{[161]}\end{array}$ & Human & $\begin{array}{l}\text { Hesperetin } \\
\text { OIM }\end{array}$ & None & ALP assay & Significant increase in ALP activity. \\
\hline $\begin{array}{l}\text { Kong et al. } 2013 \\
{[162]}\end{array}$ & Human & OIM & None & ALP assay & $\begin{array}{l}\text { Periodontal disease derived PDLSC } \\
\text { displayed impaired osteogenesis } \\
\text { compared to healthy PDLSC. }\end{array}$ \\
\hline $\begin{array}{l}\text { Singhatanadgit and } \\
\text { Varodomrujiranon } \\
2013 \text { [163] }\end{array}$ & Human & $\begin{array}{l}\text { OIM } \\
\text { spheroid } \\
\text { culture }\end{array}$ & Conical polypropylene tube & Staining & $\begin{array}{l}\text { Bone like deposit seen. PDLSC may } \\
\text { undergo osteogenic differentiation in } \\
\text { an osteogenic scaffold-free 3D } \\
\text { spheroidal culture. }\end{array}$ \\
\hline
\end{tabular}


(h) Continued.

\begin{tabular}{|c|c|c|c|c|c|c|c|}
\hline \multirow{2}{*}{$\begin{array}{l}\text { Reference } \\
\text { Yu et al. } 2013[164]\end{array}$} & $\begin{array}{c}\text { Cell } \\
\text { source }\end{array}$ & Medium & \multicolumn{2}{|c|}{ Scaffold/carriers/cues/markers } & $\begin{array}{l}\text { Evaluation } \\
\text { methods }\end{array}$ & \multicolumn{2}{|c|}{ Observation } \\
\hline & Human & OIM & \multicolumn{2}{|r|}{ None } & $\begin{array}{l}\text { ALP assay } \\
\text { Histochemical } \\
\text { staining }\end{array}$ & \multicolumn{2}{|c|}{$\begin{array}{l}\text { Osteogenic differentiation of PDLSC } \\
\text { far superior to WJCMSC. }\end{array}$} \\
\hline $\begin{array}{l}\text { Hakki et al. } 2014 \\
{[165]}\end{array}$ & Human & OIM & & $\begin{array}{l}\text { Type I collagen } \\
\text { BMP6 }\end{array}$ & $\begin{array}{l}\text { Histochemical } \\
\text { staining }\end{array}$ & \multicolumn{2}{|c|}{$\begin{array}{l}\text { BMP application stimulated } \\
\text { mineralized nodule formation. }\end{array}$} \\
\hline $\begin{array}{l}\text { Jung et al. } 2014 \\
{[106]}\end{array}$ & Human & OIM & & rAd-EGFP, BMP2 & $\begin{array}{l}\text { Histochemical } \\
\text { staining }\end{array}$ & \multicolumn{2}{|c|}{$\begin{array}{l}\text { Mineralized nodule formation seen. } \\
\text { BMP } 2 \text { effectively promoted } \\
\text { osteogenesis. }\end{array}$} \\
\hline $\begin{array}{l}\text { Tang et al. } 2014 \\
{[166]}\end{array}$ & Human & OIM & \multicolumn{2}{|r|}{ None } & $\begin{array}{c}\text { ALP assay } \\
\text { Histochemical } \\
\text { staining } \\
\end{array}$ & \multicolumn{2}{|c|}{$\begin{array}{l}\text { PDLSCs have osteogenic potential } \\
\text { and low immunogenicity. }\end{array}$} \\
\hline Ye et al. 2014 [167] & Humar & \multirow[t]{2}{*}{ OIM } & & Ad-BMP9 & $\begin{array}{c}\text { ALP assay } \\
\text { Histochemical } \\
\text { staining } \\
\end{array}$ & \multirow{2}{*}{\multicolumn{2}{|c|}{$\begin{array}{l}\text { BMP } 9 \text { promoted matrix } \\
\text { mineralization. }\end{array}$}} \\
\hline \multicolumn{5}{|c|}{ (i) Multiple dental stem cells } & & & \\
\hline Reference & $\begin{array}{c}\text { Cell } \\
\text { source }\end{array}$ & Comparison & Medium & Scaffold/carriers/cues/ma & $\begin{array}{l}\text { Evalua } \\
\text { meth }\end{array}$ & & Observation \\
\hline $\begin{array}{l}\text { Koyama et al. } \\
2009[168]\end{array}$ & Human & $\begin{array}{l}\text { DPSC } \\
\text { SHED }\end{array}$ & OIM & BMP2 & $\begin{array}{r}\text { ALP a } \\
\text { Histoch } \\
\text { stain }\end{array}$ & $\begin{array}{l}\text { say } \\
\text { mical } \\
\text { ng }\end{array}$ & $\begin{array}{l}\text { No difference observed } \\
\text { between DPSC and SHED for } \\
\text { osteogenic potential. }\end{array}$ \\
\hline $\begin{array}{l}\text { Chadipiralla } \\
\text { et al. } 2010[169]\end{array}$ & Human & $\begin{array}{l}\text { SHED } \\
\text { PDLSC }\end{array}$ & $\begin{array}{l}\text { Serum- } \\
\text { free } \\
\text { OIM }\end{array}$ & $\begin{array}{l}\text { Retinoic acid } \\
\text { ITS }\end{array}$ & $\begin{array}{r}\text { ALP a } \\
\text { Histoch } \\
\text { stain }\end{array}$ & $\begin{array}{l}\text { say } \\
\text { mical } \\
\text { ng }\end{array}$ & $\begin{array}{l}\text { High proliferation rate seen in } \\
\text { PDLSC makes it a better } \\
\text { osteogenic cell source. } \\
\text { However SHED is more } \\
\text { responsive to retinoic acid. }\end{array}$ \\
\hline $\begin{array}{l}\text { Bakopoulou } \\
\text { et al. } 2011[170]\end{array}$ & Human & $\begin{array}{l}\text { DPSC } \\
\text { SCAP }\end{array}$ & OIM & None & $\begin{array}{r}\text { ALP a } \\
\text { Histoch } \\
\text { stain }\end{array}$ & $\begin{array}{l}\text { say } \\
\text { mical } \\
\text { ng }\end{array}$ & $\begin{array}{l}\text { DPSC and SCAP positive for } \\
\text { markers of both osteogenic } \\
\text { and odontogenic } \\
\text { differentiation. }\end{array}$ \\
\hline $\begin{array}{l}\text { Lee et al. } 2011 \\
{[171]}\end{array}$ & Human & $\begin{array}{l}\text { DPSC } \\
\text { PDLSC }\end{array}$ & $\begin{array}{l}\text { PRP } \\
\text { OIM }\end{array}$ & None & $\begin{array}{r}\text { ALP a } \\
\text { Histoch } \\
\text { stain }\end{array}$ & $\begin{array}{l}\text { say } \\
\text { mical } \\
\text { ng }\end{array}$ & $\begin{array}{l}\text { PRP induces osteogenic and } \\
\text { odontogenic differentiation. }\end{array}$ \\
\hline $\begin{array}{l}\text { Atari et al. } 2012 \\
{[172]}\end{array}$ & Human & $\begin{array}{c}\text { DPSC } \\
\text { DPMSC }\end{array}$ & OIM & 3D glass scaffold & $\begin{array}{r}\text { ALP a } \\
\text { Histoch } \\
\text { stain }\end{array}$ & $\begin{array}{l}\text { say } \\
\text { mical } \\
\text { ng }\end{array}$ & $\begin{array}{l}\text { DPPSCs have higher } \\
\text { expression of bone markers } \\
\text { than DPMSC. }\end{array}$ \\
\hline $\begin{array}{l}\text { Moshaverinia } \\
\text { et al. } 2012[173]\end{array}$ & Human & $\begin{array}{l}\text { PDLSC } \\
\text { GMSC }\end{array}$ & OIM & Alginate hydrogel & $\begin{array}{r}\text { SEN } \\
\text { XR } \\
\text { Stain }\end{array}$ & & $\begin{array}{l}\text { Osteogenic potential is } \\
\text { observed higher for BMMSC } \\
\text { followed by PDLSC and lowest } \\
\text { in GMSC. }\end{array}$ \\
\hline $\begin{array}{l}\text { Yang et al. } 2013 \\
{[56]}\end{array}$ & Human & $\begin{array}{l}\text { PDLSC } \\
\text { GMSC }\end{array}$ & OIM & None & $\begin{array}{r}\text { ALP a } \\
\text { Histoch } \\
\text { stain }\end{array}$ & $\begin{array}{l}\text { say } \\
\text { mical } \\
\text { ng }\end{array}$ & $\begin{array}{l}\text { PDLSC showed more effective } \\
\text { osteogenic differentiation than } \\
\text { GMSC }\end{array}$ \\
\hline $\begin{array}{l}\text { Davies et al. } \\
2014 \text { [174] }\end{array}$ & Human & $\begin{array}{l}\text { DPSC } \\
\text { ADSC } \\
\text { BMSC }\end{array}$ & OIM & None & $\begin{array}{r}\text { Micro } \\
\text { Histoch } \\
\text { stain } \\
\text { SEI }\end{array}$ & $\begin{array}{l}\text { CT } \\
\text { mical } \\
\text { ng }\end{array}$ & $\begin{array}{l}\text { High volume of mineralized } \\
\text { matrix seen in DPSC group } \\
\text { but diffused layer of low } \\
\text { density seen in SEM. }\end{array}$ \\
\hline $\begin{array}{l}\text { Moshaverinia } \\
\text { et al. } 2014 \text { [55] }\end{array}$ & Human & $\begin{array}{l}\text { PDLSC } \\
\text { GMSC }\end{array}$ & OIM & $\begin{array}{l}\text { RGD coupled alginate } \\
\text { microsphere }\end{array}$ & $\begin{array}{l}\text { Wester } \\
\text { Fluore } \\
\text { image at }\end{array}$ & $\begin{array}{l}\text { blot } \\
\text { cent } \\
\text { alysis }\end{array}$ & $\begin{array}{l}\text { Osteogenic potential of } \\
\text { BMMSC is greater than } \\
\text { PDLSC. However PDLSC } \\
\text { shows better osteogenic } \\
\text { potential than GMSC. Stem } \\
\text { cells encapsulated in RGD } \\
\text { showed enhanced } \\
\text { osteogenesis. }\end{array}$ \\
\hline
\end{tabular}


TABLE 6: Invivo comparison of osteogenic potential different Dental stem cells.

\begin{tabular}{lccc}
\hline Type of dental stem cells & $\begin{array}{c}\text { Total no of selected invivo } \\
\text { studies }\end{array}$ & $\begin{array}{c}\text { No. of studies failed to } \\
\text { show osteogenic potential }\end{array}$ & $\begin{array}{c}\text { \% of Studies showed osteogenic } \\
\text { potential }\end{array}$ \\
\hline SCAP & 4 & 0 & $100 \%$ \\
DFCS & 4 & 2 & $50 \%$ \\
GMSC & 6 & 0 & $100 \%$ \\
DPSC & 22 & 3 & $86.36 \%$ \\
SHED & 8 & 0 & $100 \%$ \\
PDLSC & 25 & 1 & $96 \%$ \\
\hline
\end{tabular}

4.3. GMSCs. Two different sources were used in the studies (human, dog). Rats/mice and dogs were used to study the bone regeneration effect. All studies showed that GMSCs were capable of undergoing osteogenic differentiation and forming new bone in the defect area. The cell number used to transplant ranged from $1 \times 10^{6}$ to $5 \times 10^{6}$.

4.4. SHEDs. Being a biological waste, SHEDs are an interesting candidate for stem cell therapies. Studies showed that they were capable of rapid proliferation and more frequent population doubling than bone marrow-derived MSCs. In vitro studies confirmed the osteogenic differentiation that rigid scaffolds supported osteogenesis, and bovine fibroblast growth factor inhibited osteogenesis. Almost all the in vivo studies used scaffolds; HA/TCP was the most frequently used carrier. All the in vivo studies confirmed the osteogenic differentiation and bone regeneration potential of SHEDs. A recent report showed that 5-year cryopreserved SHEDs were able to proliferate and undergo osteogenesis without immune reaction in a $9 \mathrm{~mm}$ mandibular defect in dogs [41].

4.5. DPSCs. Stem cell derived from dental pulp was the most studied dental stem cell for bone regeneration. Among the twenty in vivo studies, three reported that DPSCs were not able to regenerate new bone in subcutaneously implanted mice. Two studies by Annibali et al. in 2013 and 2014 [42, 43] failed to show new bone formation using human DPSCs. Zhang et al. in 2008 [44] demonstrated no evidence of bone formation in mice with rat DPSCs. Almost all the studies used scaffold. Laino et al. in 2005 [45] was able to generate in vitro living autologous bone (LAB) tissue from DPSCs, on subcutaneous implantation in rats LAB remodeled to lamellar bone in 4 weeks.

4.6. PDLSCs. PDLSC studies showed diverse source in obtaining periodontal ligament cell. More than half of the in vivo studies used dogs as a source to obtain PDLSCs, and the periodontal defect model was widely used to assess the osteogenic potential. Seo et al. [46] showed human PDLSCs failed to generate new bone in rat periodontal defects after 8 weeks of observation. Ibandronate, simvastin, VEGF, LMHF, BMP 2, and BMP 6 all seemed to enhance osteogenic potential of PDLSCs [47-50]. Silvério et al. [51] in 2010 demonstrated deciduous derived PDLSCs promoted more mineral nodule formation compared to PDLSC derived from permanent teeth in vitro.

Studies by Yamada et al. [52] showed PDLSCs derived from dog and puppy sources were able to generate $10 \mathrm{~mm}$ diameter mandibular defects with high vascularity. Wang et al. [53] demonstrated SHEDs have more osteogenic potential than DPSC in mice. Studies confirmed that PDLSC had more osteogenic and bone formation potential than GMSCs [54, 55]. However, Yang et al. [56] studies showed GMSCs had better osteogenic potential than PDLSCs in inflammatory conditions. On average, the 3 rd cell passage was used in most of the studies and the addition of scaffolds or growth factors (except b-FGF) improved osteogenesis of the dental stem cells. Although some studies used critical sized defect, most of these studies used either a small size defect or subcutaneous implantation. This jeopardized the extrapolation on outcomes in clinical situations.

Among the various osteogenic induction and growth factors (BMP, IGF, dexamethasone, VEGF, EGF, and FGF) used in the selected studies, it lacks information about the cost effectiveness, safety, and clinical relevance information. Future research should aim to address these parameters.

Most of the selected studies used FBS for culturing dental stem cells. Serum supplementation is important in ex vivo expansion of these cells for clinical use. Using serum containing medium during stem cell culture for human cell therapy is unsafe as it may transfer viral/prion disease, xenogenic antibodies especially if repeated infusions are needed [57]. While FBS based medium may be acceptable for preclinical studies, xeno-free medium is required for expanding these cells in large scale good manufacturing practices (GMP) for clinical applications [57-59]. Furthermore human cells have the possibility to take up animal proteins and present them on their membranes; thus initiating xenogeneic immune response leads to rejection [58]. As the serum condition can significantly affect cell response, it is important to obtain research data with more clinical relevance $[58,59]$. Future studies are recommended to compare the safety and efficacy, surface antigen expression, stemness, growth potential, osteogenic differentiation potential of different dental stem cells cultured in FBS, serum-free medium, allogenic human serum, autologous human serum, plasma rich protein, and plasma lysate.

To increase the scientific validity of animal studies, experiments should be appropriately designed, analyzed, and reported transparently. This not only maximizes scientific 
knowledge, but also is for ethical and economic reasons [30]. The robustness of the research increases by using sufficient animals to achieve scientific objectives and using appropriate statistical analyses to maximize the validity of the experimental outcomes [31]. Using the NC3Rs (National Center for replacement, refinement and reduction of animals in research) ARRIVE guidelines, we performed a detailed analysis of the quality of reporting and statistical analysis of the included in vivo studies. The analysis revealed a number of issues relating to reporting omissions. The majority of the articles reported age of the animals used. However, there was a lack of information about the weight, gender, and housing conditions of the animals used. The availability of online supplementary results offered by many journals to include additional information results negates the argument that researchers are constrained by the page limit $[26,31]$. In some of the in vivo studies $(n=18 / 65)$, the number of animals were simply not reported anywhere in the methodology, results, or discussion sections. Reporting the number of animals is essential to replicate the experiments or to reanalyze the data. Furthermore, 63 of 65 studies did not mention how the sample size was chosen. Determining sample size by power size or simple calculations help to design an animal research with an appropriate number of animals to detect a biologically important effect [28-32]. We cannot rule out that the researchers may have calculated/determined the number of animals but did not report that in the article. However, reporting omission can be easily rectified, as incomplete reporting means potentially flawed research [28].

In vitro preclinical research is the basic foundation for any new therapeutic approach. Although it may not replicate a dynamic environment, in vitro research provides valuable information for future research steps. The methodological quality analysis of the selected in vitro articles revealed the possibility of selection bias. Most of the articles lacked randomization, blinding, sample size calculation, and repetition of the experiments. This affects the scientific validity of experimental results. Although CONSORT guidelines are designed to be used in RCTs, we found it reasonable to apply these guidelines to in vitro studies to emphasize the quality and importance of avoiding bias in reporting or in research, because all phases of research process are interlinked [26, $28,32]$. An inadequate sample size might report incorrect results, which could eventually result in failed animal studies or clinical trials. Comparing the performance of dental stem cells with autologous bone grafts or adipose-derived MSCs or BMMSCs will be an interesting approach. Immune modulation property shown by most of the dental stem cells may provide a solution for graft rejection.

To date few clinical cases of bone tissue engineering used dental stem cells $[9,22,24]$. The main reason for the slow progress is attributed to the extrapolation of outcome from preclinical studies. Based on our observation with the selected literatures and guidelines [26-32, 60], we believe that animal study design should include well defined inclusion and exclusion criteria (study setting), a period to test the participating animals short term ability to adhere to the experimental/treatment regimen (run in period), process of random allocation of animals to the different study groups (randomization), reporting of baseline characteristics (age, sex, and weight) for the all animals in the experimental and control group, animal housing conditions, blinding in outcome assessment and data analyses, clear reporting of number of animals enrolled, followed up, and any addition or number of animals dropped out (attrition), disclosing any adverse effects to the animals during and after intervention/experiment, reporting sample size and methods used to do sample size calculation, and reporting confidence interval in addition to $P$ value (for the effect estimate and precision). These parameters will minimize the risk of confounding and selection bias. It also ensures that the outcome of the study is not affected by conscious or unconscious bias or factors unrelated to biological action. Thus improving the internal and external validity of the study. Further well designed and conducted animal randomized control trials (RCTs) will help us to generate high level of scientific evidence similar to human RCTs.

In summary, although selected studies showed dental stem cells have remarkable potential for use in bone regeneration, further well designed preclinical studies addressing optimal differentiating factors, culture medium, critical sized defect model, comparison of osteogenic potential of different dental progenitor cells, biological activity, cost effectiveness, efficacy, and safety of dental stem cells are required before clinical translation.

\section{Conclusion}

Several dental tissues identified by this review possessed dental MSCs with an osteogenic differentiation in vitro and in vivo. Regenerating lost bone tissue was feasible with dental MSCs. The easy accessibility to obtain dental MSCs made them an attractive alternative to BMMSCs for use in clinical trials to evaluate their safety and efficacy. However the current limitation, based on the quality of the literature, requires better designed in vitro or randomized control animal trials before going into clinical trials.

\section{Abbreviations}

AdBMP2: Adenovirus carrying bone morphogenetic protein

ALP: $\quad$ Alkaline phosphatase

b FGF: Basic fibroblast growth factor

BMMSC: Bone marrow derived mesenchymal stromal cell

BMP: $\quad$ Bone morphogenetic protein

Cap: Calcium phosphate

CBB: $\quad$ Ceramic bovine bone

cDPSC: Dental pulp stem cell derived from chimpanzee

Col: Collagen

CSD: Critical sized defect

CT: $\quad$ Computed tomography

DFSC: Dental follicle stem cell

DLX2: Distal less homeobox 2

DPSC: Dental pulp stem cell

ECM: Extracellular matrix 


$\begin{array}{ll}\text { EMD: } & \text { Enamel matrix derivative } \\ \text { F: } & \text { Female } \\ \text { FBS: } & \text { Fetal bovine serum } \\ \text { FCS: } & \text { Fetal calf serum } \\ \text { FGF: } & \text { Fibroblast growth factor } \\ \text { GCF: } & \text { Genipin chitosan framework } \\ \text { GCM: } & \text { Growth culture medium } \\ \text { GFP: } & \text { Green fluorescent protein } \\ \text { GDPB: } & \text { Granular deproteinized bone } \\ \text { GMSC: } & \text { Gingiva derived mesenchymal cell } \\ \text { HAP: } & \text { Hydroxy apatite } \\ \text { HGCCS: } & \text { Nanohydroxyl apatite coated genipin } \\ & \text { chitosan conjugated scaffold } \\ \text { IGF-1: } & \text { Insulin growth factor } \\ \text { ISCS: } & \text { Intrafibrillar silicified collagen scaffold } \\ \text { ITS: } & \text { Insulin transferring selenous acid } \\ \text { Kg: } & \text { Kilogram } \\ \text { LMHF: } & \text { Low magnitude high frequency } \\ \text { LST: } & \text { Laser sintered } \\ \text { m: } & \text { Month } \\ \text { M: } & \text { Male } \\ \text { MAO: } & \text { Mono arc oxygen } \\ \text { Na; na: } & \text { Not available } \\ \text { nHAC: } & \text { Nanohydroxyl apatite collagen } \\ \text { OIM: } & \text { Osteogenic induction medium } \\ \text { PCL: } & \text { Polycaprolactone } \\ \text { PDMS: } & \text { Polydimethyl siloxane } \\ \text { PET: } & \text { Positive emission tomography } \\ \text { PLCL: } & \text { Poly(L-lactide-co-epsilon-caprolactone) } \\ \text { Th: } & \text { Recombinant } \\ \text { RGD: } & \text { Arginine-glycine-aspartic acid tripeptide } \\ \text { WEG: } & \text { Tumor necrosis factor-alpha } \\ \text { WJCMSC: } & \text { Wharton jelly of umbilical cord stem cells. } \\ \text { SAPN: } & \text { Self-assembling peptide nanofibre } \\ \text { SC: } & \text { hydrogel } \\ \text { SCAP: } & \text { Subcutaneous } \\ \text { SCID: } & \text { Stem cell from apical papilla } \\ \text { SEM: } & \text { Stem cell from inflamed pulp } \\ \text { Scanning electron microscope } \\ \text { Stem cell from human exfoliated dentition } \\ \text { Titanium } \\ \text { THED }\end{array}$

\section{Conflict of Interests}

No conflict of interests exists.

\section{Acknowledgments}

The authors would like to thank the following funding agencies: Natural Sciences and Engineering Research Council (NSERC) of Canada and the Canada Research Chairs.

\section{References}

[1] R. Dimitriou, E. Jones, D. McGonagle, and P. V. Giannoudis, "Bone regeneration: current concepts and future directions," BMC Medicine, vol. 9, article 66, 2011.
[2] T. A. Einhorn, "The cell and molecular biology of fracture healing," Clinical Orthopaedics and Related Research, vol. 355, supplement, pp. S7-S21, 1998.

[3] T.-J. Cho, L. C. Gerstenfeld, and T. A. Einhorn, "Differential temporal expression of members of the transforming growth factor $\beta$ superfamily during murine fracture healing," Journal of Bone and Mineral Research, vol. 17, no. 3, pp. 513-520, 2002.

[4] P. V. Giannoudis, H. Dinopoulos, and E. Tsiridis, "Bone substitutes: an update," Injury, vol. 36, supplement 3, pp. S20-S27, 2005.

[5] A. J. Salgado, O. P. Coutinho, and R. L. Reis, "Bone tissue engineering: state of the art and future trends," Macromolecular Bioscience, vol. 4, no. 8, pp. 743-765, 2004.

[6] F. Shapiro, "Bone development and its relation to fracture repair. The role of mesenchymal osteoblasts and surface osteoblasts," European Cells and Materials, vol. 15, pp. 53-76, 2008.

[7] A. R. Amini, C. T. Laurencin, and S. P. Nukavarapu, "Bone tissue engineering: recent advances and challenges," Critical Reviews in Biomedical Engineering, vol. 40, no. 5, pp. 363-408, 2012.

[8] R. J. O'Keefe and J. Mao, "Bone tissue engineering and regeneration: from discovery to the clinic-an overview," Tissue Engineering_Part B: Reviews, vol. 17, no. 6, pp. 389-392, 2011.

[9] C. Jakobsen, J. A. Sørensen, M. Kassem, and T. H. Thygesen, "Mesenchymal stem cells in oral reconstructive surgery: a systematic review of the literature," Journal of Oral Rehabilitation, vol. 40, no. 9, pp. 693-706, 2013.

[10] J. S. Pieper, T. Hafmans, J. H. Veerkamp, and T. H. van Kuppevelt, "Development of tailor-made collagen-glycosaminoglycan matrices: EDC/NHS crosslinking, and ultrastructural aspects," Biomaterials, vol. 21, no. 6, pp. 581-593, 2000.

[11] H. B. M. van der Lubbe, C. P. A. T. Klein, and K. de Groot, "A simple method for preparing thin $(10 \mu \mathrm{m})$ histological sections of undecalcified plastic embedded bone with implants," Stain Technology, vol. 63, no. 3, pp. 171-176, 1988.

[12] S. Hemmat, D. M. Lieberman, and S. P. Most, "An introduction to stem cell biology," Facial Plastic Surgery, vol. 26, no. 5, pp. 343-349, 2010.

[13] L. da Silva Meirelles and N. B. Nardi, "Methodology, biology and clinical applications of mesenchymal stem cells," Frontiers in Bioscience, vol. 14, no. 11, pp. 4281-4298, 2009.

[14] M. Camassola, L. M. G. de MacEdo Braga, P. C. Chagastelles, and N. B. Nardi, "Methodology, biology and clinical applications of human mesenchymal stem cells," Methods in Molecular Biology, vol. 879, pp. 491-504, 2012.

[15] M. F. Pittenger, A. M. Mackay, S. C. Beck et al., "Multilineage potential of adult human mesenchymal stem cells," Science, vol. 284, no. 5411, pp. 143-147, 1999.

[16] E. A. Jones and X. B. Yang, "Mesenchymal stem cells and their future in bone repair," International Journal of Advanced Rheumatology, vol. 3, no. 3, pp. 15-21, 2005.

[17] B. M. Abdallah and M. Kassem, "Human mesenchymal stem cells: from basic biology to clinical applications," Gene Therapy, vol. 15, no. 2, pp. 109-116, 2008.

[18] H. Zigdon-Giladi, N. Khoury, and A. Evron, "Adult stem cells in the use of jaw bone regeneration: current and prospective research," Quintessence International, vol. 46, no. 2, pp. 125-131, 2015.

[19] P. Bianco and P. G. Robey, "Marrow stromal stem cells," Journal of Clinical Investigation, vol. 105, no. 12, pp. 1663-1668, 2000.

[20] W. Sonoyama, Y. Liu, T. Yamaza et al., "Characterization of the apical papilla and its residing stem cells from human immature 
permanent teeth: a pilot study," Journal of Endodontics, vol. 34, no. 2, pp. 166-171, 2008.

[21] R. J. Waddington, S. J. Youde, C. P. Lee, and A. J. Sloan, "Isolation of distinct progenitor stem cell populations from dental pulp," Cells Tissues Organs, vol. 189, no. 1-4, pp. 268-274, 2008.

[22] E. MacHado, M. H. Fernandes, and P. de Sousa Gomes, "Dental stem cells for craniofacial tissue engineering," Oral Surgery, Oral Medicine, Oral Pathology and Oral Radiology, vol. 113, no. 6, pp. 728-733, 2012.

[23] N. Kawashima, "Characterisation of dental pulp stem cells: a new horizon for tissue regeneration?" Archives of Oral Biology, vol. 57, no. 11, pp. 1439-1458, 2012.

[24] G. Morad, L. Kheiri, and A. Khojasteh, "Dental pulp stem cells for in vivo bone regeneration: a systematic review of literature," Archives of Oral Biology, vol. 58, no. 12, pp. 1818-1827, 2013.

[25] R. Bright, K. Hynes, S. Gronthos, and P. M. Bartold, "Periodontal ligament-derived cells for periodontal regeneration in animal models: a systematic review," Journal of Periodontal Research, 2014.

[26] C. M. Faggion Jr., "Guidelines for reporting pre-clinical in vitro studies on dental materials," Journal of Evidence-Based Dental Practice, vol. 12, no. 4, pp. 182-189, 2012.

[27] M. W. Festing, P. Overend, R. Gaines Das, M. Cortina Borja, and M. Berdoy, "The design of animal experiments: reducing the use of animals in research through better experimental design," in Laboratory Animal Handbooks, no. 14, pp. 1-16, Royal Society of Medicine Press (Laboratories Animals Limited), London, UK, 2002.

[28] M. R. Macleod, M. Fisher, V. O'Collins et al., "Good laboratory practice: preventing introduction of bias at the bench," Stroke, vol. 40, no. 3, pp. 50-52, 2009.

[29] C. Kilkenny, N. Parsons, E. Kadyszewski et al., "Survey of the quality of experimental design, statistical analysis and reporting of research using animals," PLoS ONE, vol. 4, no. 11, Article ID e7824, 2009.

[30] F. Schwarz, G. Iglhaut, and J. Becker, "Quality assessment of reporting of animal studies on pathogenesis and treatment of peri-implant mucositis and peri-implantitis. A systematic review using the ARRIVE guidelines," Journal of Clinical Periodontology, vol. 39, supplement 12, pp. 63-72, 2012.

[31] D. Krauth, T. J. Woodruff, and L. Bero, "Instruments for assessing risk of bias and other methodological criteria of published animal studies: a systematic review," Environmental Health Perspectives, vol. 121, no. 9, pp. 985-992, 2013.

[32] A. C. Plint, D. Moher, A. Morrison et al., "Does the CONSORT checklist improve the quality of reports of randomised controlled trials? A systematic review," The Medical Journal of Australia, vol. 185, no. 5, pp. 263-267, 2006.

[33] S. Gronthos, M. Mankani, J. Brahim, P. G. Robey, and S. Shi, "Postnatal human dental pulp stem cells (DPSCs) in vitro and in vivo," Proceedings of the National Academy of Sciences of the United States of America, vol. 97, no. 25, pp. 13625-13630, 2000.

[34] M. Dominici, K. Le Blanc, I. Mueller et al., "Minimal criteria for defining multipotent mesenchymal stromal cells. The International Society for Cellular Therapy position statement," Cytotherapy, vol. 8, no. 4, pp. 315-317, 2006.

[35] S. Wang, J. Mu, Z. Fan et al., "Insulin-like growth factor 1 can promote the osteogenic differentiation and osteogenesis of stem cells from apical papilla," Stem Cell Research, vol. 8, no. 3, pp. 346-356, 2012.
[36] J. Wu, G. T.-J. Huang, W. He et al., "Basic fibroblast growth factor enhances stemness of human stem cells from the apical papilla," Journal of Endodontics, vol. 38, no. 5, pp. 614-622, 2012.

[37] L.-L. Xu, H.-C. Liu, D.-S. Wang et al., "Effects of BMP-2 and dexamethasone on osteogenic differentiation of rat dental follicle progenitor cells seeded on three-dimensional $\beta$-TCP," Biomedical Materials, vol. 4, no. 6, Article ID 065010, 2009.

[38] S. Tsuchiya, S. Ohshima, Y. Yamakoshi, J. P. Simmer, and M. J. Honda, "Osteogenic differentiation capacity of porcine dental follicle progenitor cells," Connective Tissue Research, vol. 51, no. 3, pp. 197-207, 2010.

[39] M. J. Honda, M. Imaizumi, H. Suzuki, S. Ohshima, S. Tsuchiya, and K. Satomura, "Stem cells isolated from human dental follicles have osteogenic potential," Oral Surgery, Oral Medicine, Oral Pathology, Oral Radiology and Endodontology, vol. 111, no. 6, pp. 700-708, 2011.

[40] M. Rezai Rad, G. E. Wise, H. Brooks, M. B. Flanagan, and S. Yao, "Activation of proliferation and differentiation of dental follicle stem cells (DFSCs) by heat stress," Cell Proliferation, vol. 46, no. 1, pp. 58-66, 2013.

[41] A. Behnia, A. Haghighat, A. Talebi, N. Nourbakhsh, and F. Heidari, "Transplantation of stem cells from human exfoliated deciduous teeth for bone regeneration in the dog mandibular defect," World Journal of Stem Cells, vol. 6, no. 4, pp. 505-510, 2014.

[42] S. Annibali, A. Cicconetti, M. P. Cristalli et al., "A comparative morphometric analysis of biodegradable scaffolds as carriers for dental pulp and periosteal stem cells in a model of bone regeneration," Journal of Craniofacial Surgery, vol. 24, no. 3, pp. 866-871, 2013.

[43] S. Annibali, D. Bellavia, L. Ottolenghi et al., "Micro-CT and PET analysis of bone regeneration induced by biodegradable scaffolds as carriers for dental pulp stem cells in a rat model of calvarial 'critical size' defect: preliminary data," Journal of Biomedical Materials Research Part B: Applied Biomaterials, vol. 102, no. 4, pp. 815-825, 2014.

[44] W. Zhang, X. F. Walboomers, G. J. V. M. van Osch, J. van den Dolder, and J. A. Jansen, "Hard tissue formation in a porous HA/TCP ceramic scaffold loaded with stromal cells derived from dental pulp and bone marrow," Tissue Engineering Part A, vol. 14, no. 2, pp. 285-294, 2008.

[45] G. Laino, R. D’Aquino, A. Graziano et al., "A new population of human adult dental pulp stem cells: a useful source of living autologous fibrous bone tissue (LAB)," Journal of Bone and Mineral Research, vol. 20, no. 8, pp. 1394-1402, 2005.

[46] B. M. Seo, M. Miura, S. Gronthos et al., "Investigation of multipotent postnatal stem cells from human periodontal ligament," The Lancet, vol. 364, no. 9429, pp. 149-155, 2004.

[47] J.-H. Lee, S. Um, J.-H. Jang, and B. M. Seo, "Effects of VEGF and FGF-2 on proliferation and differentiation of human periodontal ligament stem cells," Cell and Tissue Research, vol. 348, no. 3, pp. 475-484, 2012.

[48] Y. Yu, J. Mu, Z. Fan et al., "Insulin-like growth factor 1 enhances the proliferation and osteogenic differentiation of human periodontal ligament stem cells via ERK and JNK MAPK pathways," Histochemistry \& Cell Biology, vol. 137, no. 4, pp. 513-525, 2012.

[49] Q. Zhou, Z.-N. Zhao, J.-T. Cheng et al., "Ibandronate promotes osteogenic differentiation of periodontal ligament stem cells by regulating the expression of microRNAs," Biochemical and Biophysical Research Communications, vol. 404, no. 1, pp. 127132, 2011. 
[50] C. Zhang, J. Li, L. Zhang et al., "Effects of mechanical vibration on proliferation and osteogenic differentiation of human periodontal ligament stem cells," Archives of Oral Biology, vol. 57, no. 10, pp. 1395-1407, 2012.

[51] K. G. Silvério, T. L. Rodrigues, R. Dela Coletta et al., "Mesenchymal stem cell properties of periodontal ligament cells from deciduous and permanent teeth," Journal of Periodontology, vol. 81, no. 8, pp. 1207-1215, 2010.

[52] Y. Yamada, K. Ito, S. Nakamura, M. Ueda, and T. Nagasaka, "Promising cell-based therapy for bone regeneration using stem cells from deciduous teeth, dental pulp, and bone marrow," Cell Transplantation, vol. 20, no. 7, pp. 1003-1013, 2011.

[53] X. Wang, X.-J. Sha, G.-H. Li et al., "Comparative characterization of stem cells from human exfoliated deciduous teeth and dental pulp stem cells," Archives of Oral Biology, vol. 57, no. 9, pp. 1231-1240, 2012.

[54] A. Moshaverinia, C. Chen, K. Akiyama et al., "Encapsulated dental-derived mesenchymal stem cells in an injectable and biodegradable scaffold for applications in bone tissue engineering," Journal of Biomedical Materials Research-Part A, vol. 101, no. 11, pp. 3285-3294, 2013.

[55] A. Moshaverinia, C. Chen, X. Xu et al., "Bone regeneration potential of stem cells derived from periodontal ligament or gingival tissue sources encapsulated in RGD-modified alginate scaffold," Tissue Engineering-Part A, vol. 20, no. 3-4, pp. 611621, 2014.

[56] H. Yang, L.-N. Gao, Y. An et al., "Comparison of mesenchymal stem cells derived from gingival tissue and periodontal ligament in different incubation conditions," Biomaterials, vol. 34, no. 29, pp. 7033-7047, 2013.

[57] K. Bieback, A. Hecker, A. Kocaömer et al., "Human alternatives to fetal bovine serum for the expansion of mesenchymal stromal cells from bone marrow," Stem Cells, vol. 27, no. 9, pp. 2331-2341, 2009.

[58] B. Lindroos, S. Boucher, L. Chase et al., "Serum-free, xeno-free culture media maintain the proliferation rate and multipotentiality of adipose stem cells in vitro," Cytotherapy, vol. 11, no. 7, pp. 958-972, 2009.

[59] L. Kyllönen, S. Haimi, B. Mannerström et al., "Effects of different serum conditions on osteogenic differentiation of human adipose stem cells in vitro," Stem Cell Research and Therapy, vol. 4, no. 1, article 17, pp. 1-15, 2013.

[60] B. S. Muhlhausler, F. H. Bloomfield, and M. W. Gillman, "Whole animal experiments should be more like human randomized controlled trials," PLoS Biology, vol. 11, no. 2, Article ID e1001481, 2013.

[61] S. Abe, S. Yamaguchi, A. Watanabe, K. Hamada, and T. Amagasa, "Hard tissue regeneration capacity of apical pulp derived cells (APDCs) from human tooth with immature apex," Biochemical and Biophysical Research Communications, vol. 371, no. 1, pp. 90-93, 2008.

[62] S. Abe, K. Hamada, M. Miura, and S. Yamaguchi, "Neural crest stem cell property of apical pulp cells derived from human developing tooth," Cell Biology International, vol. 36, no. 10, pp. 927-936, 2012.

[63] L. Wang, M. Yan, Y. Wang et al., "Proliferation and osteo/odontoblastic differentiation of stem cells from dental apical papilla in mineralization-inducing medium containing additional $\mathrm{KH}_{2} \mathrm{PO}_{4}$," Cell Proliferation, vol. 46, no. 2, pp. 214-222, 2013.

[64] B. Qu, O. Liu, X. Fang et al., "Distal-less homeobox 2 promotes the osteogenic differentiation potential of stem cells from apical papilla," Cell and Tissue Research, vol. 357, pp. 133-143, 2014.
[65] B. W. Park, E. J. Kang, J. H. Byun et al., "In vitro and in vivo osteogenesis of human mesenchymal stem cells derived from skin, bone marrow and dental follicle tissues," Differentiation, vol. 83, no. 5, pp. 249-259, 2012.

[66] F. Wang, M. Yu, X. Yan et al., "Gingiva-derived mesenchymal stem cell-mediated therapeutic approach for bone tissue regeneration," Stem Cells and Development, vol. 20, no. 12, pp. 20932102, 2011.

[67] X. Yu, S. Ge, S. Chen et al., "Human gingiva-derived mesenchymal stromal cells contribute to periodontal regeneration in beagle dogs," Cells Tissues Organs, vol. 198, pp. 428-437, 2014.

[68] Q. C. Xu, Z. G. Wang, Q. X. Ji et al., "Systemically transplanted human gingiva-derived mesenchymal stem cells contributing to bone tissue regeneration," International Journal of Clinical and Experimental Pathology, vol. 7, no. 8, pp. 4922-4929, 2014.

[69] M. Miura, S. Gronthos, M. Zhao et al., "SHED: stem cells from human exfoliated deciduous teeth," Proceedings of the National Academy of Sciences of the United States of America, vol. 100, no. 10, pp. 5807-5812, 2003.

[70] B. M. Seo, W. Sonoyama, T. Yamaza et al., "SHED repair criticalsize calvarial defects in mice," Oral Diseases, vol. 14, no. 5, pp. 428-434, 2008.

[71] Y. Zheng, Y. Liu, C. M. Zhang et al., "Stem cells from deciduous tooth repair mandibular defect in swine," Journal of Dental Research, vol. 88, no. 3, pp. 249-254, 2009.

[72] B. Li, C. Qu, C. Chen et al., "Basic fibroblast growth factor inhibits osteogenic differentiation of stem cells from human exfoliated deciduous teeth through ERK signaling," Oral Diseases, vol. 18, no. 3, pp. 285-292, 2012.

[73] I. V. Vakhrushev, E. N. Antonov, A. V. Popova et al., "Design of tissue engineering implants for bone tissue regeneration of the basis of new generation polylactoglycolide scaffolds and multipotent mesenchymal stem cells from human exfoliated deciduous teeth (SHED Cells)," Bulletin of Experimental Biology and Medicine, vol. 153, no. 1, pp. 143-147, 2012.

[74] A. Alkaisi, A. R. Ismail, S. S. Mutum, Z. A. Rifin Ahmad, S. Masudi, and N. H. A. Razak, "Transplantation of human dental pulp stem cells: enhance bone consolidation in mandibular distraction osteogenesis," Journal of Oral and Maxillofacial Surgery, vol. 71, no. 10, pp. 1758.e1-1758.e13, 2013.

[75] G. Laino, A. Graziano, R. D’Aquino et al., "An approachable human adult stem cell source for hard-tissue engineering," Journal of Cellular Physiology, vol. 206, no. 3, pp. 693-701, 2006.

[76] S. Otaki, S. Ueshima, K. Shiraishi et al., "Mesenchymal progenitor cells in adult human dental pulp and their ability to form bone when transplanted into immunocompromised mice," Cell Biology International, vol. 31, no. 10, pp. 1191-1197, 2007.

[77] A. de Mendonça Costa, D. F. Bueno, M. T. Martins et al., "Reconstruction of large cranial defects in nonimmunosuppressed experimental design with human dental pulp stem cells," Journal of Craniofacial Surgery, vol. 19, no. 1, pp. 204-210, 2008.

[78] A. Morito, Y. Kida, K. Suzuki et al., "Effects of basic fibroblast growth factor on the development of the stem cell properties of human dental pulp cells," Archives of Histology and Cytology, vol. 72, no. 1, pp. 51-64, 2009.

[79] X. Yang, P. M. van der Kraan, Z. Bian, M. Fan, X. F. Walboomers, and J. A. Jansen, "Mineralized tissue formation by BMP2transfected pulp stem cells," Journal of Dental Research, vol. 88, no. 11, pp. 1020-1025, 2009.

[80] D. C. E. Kraft, D. A. Bindslev, B. Melsen, B. M. Abdallah, M. Kassem, and J. Klein-Nulend, "Mechanosensitivity of dental 
pulp stem cells is related to their osteogenic maturity," European Journal of Oral Sciences, vol. 118, no. 1, pp. 29-38, 2010.

[81] B. Chan, R. W. K. Wong, and B. Rabie, "In vivo production of mineralised tissue pieces for clinical use: a qualitative pilot study using human dental pulp cell," International Journal of Oral and Maxillofacial Surgery, vol. 40, no. 6, pp. 612-620, 2011.

[82] K. Ito, Y. Yamada, S. Nakamura, and M. Ueda, "Osteogenic potential of effective bone engineering using dental pulp stem cells, bone marrow stem cells, and periosteal cells for osseointegration of dental implants," The International Journal of Oral \& Maxillofacial Implants, vol. 26, no. 5, pp. 947-954, 2011.

[83] J.-H. Li, D.-Y. Liu, F.-M. Zhang, F. Wang, W.-K. Zhang, and Z.-T. Zhang, "Human dental pulp stem cell is a promising autologous seed cell for bone tissue engineering," Chinese Medical Journal, vol. 124, no. 23, pp. 4022-4028, 2011.

[84] H. C. Liu, L. L. Eo, D. S. Wang, F. Su, X. Wu, and Z. P. Shi, "Reconstruction of alveolar bone defects using bone morphogenetic protein 2 mediated rabbit dental pulp stem cells seeded on nano-hydroxyapatite/collagen/poly(L-lactide)," Tissue Engineering A, vol. 17, no. 19-20, pp. 2417-2433, 2011.

[85] A. Pisciotta, M. Riccio, G. Carnevale et al., "Human serum promotes osteogenic differentiation of human dental pulp stem cells in vitro and in vivo," PLOS ONE, vol. 7, no. 11, Article ID e50542, 2012.

[86] M. Riccio, T. Maraldi, A. Pisciotta et al., "Fibroin scaffold repairs critical-size bone defects in vivo supported by human amniotic fluid and dental pulp stem cells," Tissue Engineering A, vol. 18, no. 9-10, pp. 1006-1013, 2012.

[87] A. Khorsand, M. B. Eslaminejad, M. Arabsolghar et al., "Autologous dental pulp stem cells in regeneration of defect created in canine periodontal tissue," Journal of Oral Implantology, vol. 39, no. 4, pp. 433-443, 2013.

[88] T. Maraldi, M. Riccio, A. Pisciotta et al., "Human amniotic fluid-derived and dental pulp-derived stem cells seeded into collagen scaffold repair critical-size bone defects promoting vascularization," Stem Cell Research and Therapy, vol. 4, no. 3, article 53, 2013.

[89] Y. Wang, M. Yan, Y. Yu, J. Wu, J. Yu, and Z. Fan, "Estrogen deficiency inhibits the odonto/osteogenic differentiation of dental pulp stem cells via activation of the NF- $\kappa$ B pathway," Cell and Tissue Research, vol. 352, no. 3, pp. 551-559, 2013.

[90] L. E. Ling, L. Feng, H. C. Liu, D. S. Wang, Z. P. Shi, J. C. Wang et al., "The effect of calcium phosphate composite scaffolds on the osteogenic differentiation of rabbit dental pulp stem cells," Journal of Biomedical Materials Research Part A, 2014.

[91] L.-N. Niu, J.-Q. Sun, Q.-H. Li et al., "Intrafibrillar-silicified collagen scaffolds enhance the osteogenic capacity of human dental pulp stem cells," Journal of Dentistry, vol. 42, pp. 839849, 2014.

[92] A. Doǧan, A. Özdemir, A. Kubar, and T. Oygür, "Assessment of periodontal healing by seeding of fibroblast-like cells derived from regenerated periodontal ligament in artificial furcation defects in a dog: a pilot study," Tissue Engineering, vol. 8, no. 2, pp. 273-282, 2002.

[93] Y. Murano, M. Ota, A. Katayama, H. Sugito, Y. Shibukawa, and S. Yamada, "Periodontal regeneration following transplantation of proliferating tissue derived from periodontal ligament into class III furcation defects in dogs," Biomedical Research, vol. 27, no. 3, pp. 139-147, 2006.

[94] T. Iwata, M. Yamato, H. Tsuchioka et al., "Periodontal regeneration with multi-layered periodontal ligament-derived cell sheets in a canine model," Biomaterials, vol. 30, no. 14, pp. $2716-$ $2723,2009$.

[95] S. H. Kim, K. H. Kim, B. M. Seo et al., "Alveolar bone regeneration by transplantation of periodontal ligament stem cells and bone marrow stem cells in a canine peri-implant defect model: a Pilot Study," Journal of Periodontology, vol. 80, no. 11, pp. 18151823, 2009.

[96] G. Ding, Y. Liu, W. Wang et al., "Allogeneic periodontal ligament stem cell therapy for periodontitis in swine," Stem Cells, vol. 28, no. 10, pp. 1829-1838, 2010.

[97] H. He, J. Yu, J. Cao et al., "Biocompatibility and osteogenic capacity of periodontal ligament stem cells on nHAC/PLA and HA/TCP scaffolds," Journal of Biomaterials Science, Polymer Edition, vol. 22, no. 1-3, pp. 179-194, 2011.

[98] W.-D. Grimm, A. Dannan, S. Becher et al., "The ability of human periodontium-derived stem cells to regenerate periodontal tissues: a preliminary in vivo investigation," The International Journal of Periodontics \& Restorative Dentistry, vol. 31, no. 6, pp. e94-e101, 2011.

[99] F. F. Suaid, F. V. Ribeiro, T. R. L. E. S. Gomes et al., "Autologous periodontal ligament cells in the treatment of class III furcation defects: a study in dogs," Journal of Clinical Periodontology, vol. 39, no. 4, pp. 377-384, 2012.

[100] G. Tour, M. Wendel, G. Moll, and I. Tcacencu, "Bone repair using periodontal ligament progenitor cell-seeded constructs," Journal of Dental Research, vol. 91, no. 8, pp. 789-794, 2012.

[101] L.-N. Gao, Y. An, M. Lei et al., "The effect of the coumarinlike derivative osthole on the osteogenic properties of human periodontal ligament and jaw bone marrow mesenchymal stem cell sheets," Biomaterials, vol. 34, no. 38, pp. 9937-9951, 2013.

[102] S. Ge, N. Zhao, L. Wang, H. Liu, and P. Yang, "Effects of hydroxyapatite nanostructure on channel surface of porcine acellular dermal matrix scaffold on cell viability and osteogenic differentiation of human periodontal ligament stem cells," International Journal of Nanomedicine, vol. 8, pp. 1887-1895, 2013.

[103] K. M. Mrozik, N. Wada, V. Marino et al., "Regeneration of periodontal tissues using allogeneic periodontal ligament stem cells in an ovine model," Regenerative Medicine, vol. 8, no. 6, pp. 711-723, 2013.

[104] N. Yu, L. Prodanov, J. Te Riet, F. Yang, X. F. Walboomers, and J. A. Jansen, "Regulation of periodontal ligament cell behavior by cyclic mechanical loading and substrate nanotexture," Journal of Periodontology, vol. 84, no. 10, pp. 1504-1513, 2013.

[105] J. Han, D. Menicanin, V. Marino et al., "Assessment of the regenerative potential of allogeneic periodontal ligament stem cells in a rodent periodontal defect model," Journal of Periodontal Research, vol. 49, no. 3, pp. 333-345, 2014.

[106] I.-H. Jung, S.-H. Lee, C.-M. Jun, N. Oh, and J.-H. Yun, “Characterization of the enhanced bone regenerative capacity of human periodontal ligament stem cells engineered to express the gene encoding bone morphogenetic protein 2," Tissue Engineering A, vol. 20, no. 15-16, pp. 2189-2199, 2014.

[107] S.-Y. Park, K.-H. Kim, E.-H. Gwak et al., "Ex vivo bone morphogenetic protein 2 gene delivery using periodontal ligament stem cells for enhanced re-osseointegration in the regenerative treatment of peri-implantitis," Journal of Biomedical Materials Research A, vol. 103, no. 1, pp. 38-47, 2015.

[108] B.-H. Yu, Q. Zhou, and Z.-L. Wang, "Periodontal ligament versus bone marrow mesenchymal stem cells in combination with Bio-Oss scaffolds for ectopic and in situ bone formation: 
a comparative study in the rat," Journal of Biomaterials Applications, vol. 29, no. 2, pp. 243-253, 2014.

[109] B.-H. Yu, Q. Zhou, and Z.-L. Wang, "Comparison of tissueengineered bone from different stem cell sources for maxillary sinus floor augmentation: a study in a canine model," Journal of Oral and Maxillofacial Surgery, vol. 72, no. 6, pp. 1084-1092, 2014.

[110] B.-J. Zhao and Y.-H. Liu, "Simvastatin induces the osteogenic differentiation of human periodontal ligament stem cells," Fundamental \& Clinical Pharmacology, vol. 28, no. 5, pp. 583592, 2014.

[111] B. W. Park, Y. S. Hah, M. J. Choi et al., "In vitro osteogenic differentiation of cultured human dental papilla-derived cells," Journal of Oral \& Maxillofacial Surgery, vol. 67, no. 3, pp. 507514, 2009.

[112] E. Ikeda, M. Hirose, N. Kotobuki et al., "Osteogenic differentiation of human dental papilla mesenchymal cells," Biochemical and Biophysical Research Communications, vol. 342, no. 4, pp. 1257-1262, 2006.

[113] S. Viale-Bouroncle, F. Völlner, C. Möhl et al., "Soft matrix supports osteogenic differentiation of human dental follicle cells," Biochemical and Biophysical Research Communications, vol. 410, no. 3, pp. 587-592, 2011.

[114] H. Aonuma, N. Ogura, K. Takahashi et al., "Characteristics and osteogenic differentiation of stem/progenitor cells in the human dental follicle analyzed by gene expression profiling," Cell and Tissue Research, vol. 350, no. 2, pp. 317-331, 2012.

[115] C. Li, X. Yang, Y. He et al., "Bone morphogenetic protein-9 induces osteogenic differentiation of rat dental follicle stem cells in P38 and ERK1/2 MAPK dependent manner," International Journal of Medical Sciences, vol. 9, no. 10, pp. 862-871, 2012.

[116] G. Mori, A. Ballini, C. Carbone et al., "Osteogenic differentiation of dental follicle stem cells," International Journal of Medical Sciences, vol. 9, no. 6, pp. 480-487, 2012.

[117] K. Takahashi, N. Ogura, H. Aonuma et al., "Bone morphogenetic protein 6 stimulates mineralization in human dental follicle cells without dexamethasone," Archives of Oral Biology, vol. 58, no. 6, pp. 690-698, 2013.

[118] S. Yao, H. He, D. L. Gutierrez et al., "Expression of bone morphogenetic protein- 6 in dental follicle stem cells and its effect on osteogenic differentiation," Cells Tissues Organs, vol. 198, no. 6, pp. 438-447, 2013.

[119] Ö. Degistirici, F. Grabellus, S. Irsen, K. W. Schmid, and M. Thie, "Using human neural crest-derived progenitor cells to investigate osteogenesis: an in vitro study," Matrix Biology, vol. 29, no. 3, pp. 219-227, 2010.

[120] I. V. Vakhrushev, Y. G. Suzdaltseva, V. V. Burunova, P. A. Karalkin, A. Y. Lupatov, and K. N. Yarygin, "Mesenchymal cells of the deciduous tooth pulp: cytophenotype and initial evaluation of possibility of their use in bone tissue engineering," Bulletin of Experimental Biology and Medicine, vol. 149, no. 1, pp. 161-165, 2010.

[121] S. Viale-Bouroncle, M. Gosau, K. Küpper et al., "Rigid matrix supports osteogenic differentiation of stem cells from human exfoliated deciduous teeth (SHED)," Differentiation, vol. 84, no. 5, pp. 366-370, 2012.

[122] I. V. Vakhrushev, V. V. Smirnov, M. A. Goldberg et al., "Effect of calcium phosphate materials on multipotent mesenchymal cells from exfoliated deciduous teeth (SHED cells) in vitro," Bulletin of Experimental Biology and Medicine, vol. 155, no. 1, pp. 139144, 2013.
[123] I. Karadzic, V. Vucic, V. Jokanovic et al., "Effects of novel hydroxyapatite-based 3D biomaterials on proliferation and osteoblastic differentiation of mesenchymal stem cells," Journal of Biomedical Materials Research Part A, pp. 350-357, 2014.

[124] S. Yu, S. Diao, J. Wang, G. Ding, D. Yang, and Z. Fan, "Comparative analysis of proliferation and differentiation potentials of stem cells from inflamed pulp of deciduous teeth and stem cells from exfoliated deciduous teeth," BioMed Research International, vol. 2014, Article ID 930907, 12 pages, 2014.

[125] R. d'Aquino, A. Graziano, M. Sampaolesi et al., "Human postnatal dental pulp cells co-differentiate into osteoblasts and endotheliocytes: a pivotal synergy leading to adult bone tissue formation," Cell Death and Differentiation, vol. 14, no. 6, pp. 1162-1171, 2007.

[126] P.-H. Cheng, B. Snyder, D. Fillos, C. C. Ibegbu, A. H.-C. Huang, and A. W. S. Chan, "Postnatal stem/progenitor cells derived from the dental pulp of adult chimpanzee," BMC Cell Biology, vol. 9, article 20, 2008.

[127] A. Graziano, R. D’Aquino, M. G. Cusella-De Angelis et al., "Scaffold's surface geometry significantly affects human stem cell bone tissue engineering," Journal of Cellular Physiology, vol. 214, no. 1, pp. 166-172, 2008.

[128] D. L. Alge, D. Zhou, L. L. Adams et al., "Donor-matched comparison of dental pulp stem cells and bone marrow-derived mesenchymal stem cells in a rat model," Journal of Tissue Engineering \& Regenerative Medicine, vol. 4, no. 1, pp. 73-81, 2010.

[129] M.-J. Han, Y.-K. Seo, H.-H. Yoon, K.-Y. Song, and J.-K. Park, "Upregulation of bone-like extracellular matrix expression in human dental pulp stem cells by mechanical strain," Biotechnology and Bioprocess Engineering, vol. 15, no. 4, pp. 572-579, 2010.

[130] C. Mangano, A. de Rosa, V. Desiderio et al., "The osteoblastic differentiation of dental pulp stem cells and bone formation on different titanium surface textures," Biomaterials, vol. 31, no. 13, pp. 3543-3551, 2010.

[131] G. Mori, M. Centonze, G. Brunetti et al., "Osteogenic properties of human dental pulp stem cells," Journal of Biological Regulators and Homeostatic Agents, vol. 24, no. 2, pp. 167-175, 2010.

[132] L. Spath, V. Rotilio, M. Alessandrini et al., "Explant-derived human dental pulp stem cells enhance differentiation and proliferation potentials," Journal of Cellular and Molecular Medicine, vol. 14, no. 6 B, pp. 1635-1644, 2010.

[133] D. Galli, L. Benedetti, M. Bongio et al., "In vitro osteoblastic differentiation of human mesenchymal stem cells and human dental pulp stem cells on poly-L-lysine-treated titanium6-aluminium-4-vanadium," Journal of Biomedical Materials Research-Part A, vol. 97, no. 2, pp. 118-126, 2011.

[134] I. D’Alimonte, E. Nargi, F. Mastrangelo et al., "Vascular endothelial growth factor enhances in vitro proliferation and osteogenic differentiation of human dental pulp stem cells," Journal of Biological Regulators and Homeostatic Agents, vol. 25, no. 1, pp. 57-69, 2011.

[135] C. Mangano, F. Paino, R. d’Aquino et al., "Human Dental Pulp Stem Cells hook into Biocoral scaffold forming an engineered biocomplex," PLoS ONE, vol. 6, no. 4, Article ID e18721, 2011.

[136] T. Struys, M. Moreels, W. Martens, R. Donders, E. Wolfs, and I. Lambrichts, "Ultrastructural and immunocytochemical analysis of multilineage differentiated human dental pulp- and umbilical cord-derived mesenchymal stem cells," Cells Tissues Organs, vol. 193, no. 6, pp. 366-378, 2011.

[137] X.-F. Huang, S.-J. Yuan, and C. Yang, "Effects of total flavonoids from Drynaria fortunei on the proliferation and osteogenic 
differentiation of rat dental pulp stem cells," Molecular Medicine Reports, vol. 6, no. 3, pp. 547-552, 2012.

[138] Y. Huang, T. Chang, C. Yang, and M. Wu, "Mineralized and osteoid tissue from dental pulp stem cells on micro-arc oxidation titanium in vitro," Journal of Huazhong University of Science and Technology: Medical Science, vol. 32, no. 4, pp. 620-625, 2012.

[139] R. Khanna-Jain, B. Mannerström, A. Vuorinen, G. K. B. Sándor, R. Suuronen, and S. Miettinen, "Osteogenic differentiation of human dental pulp stem cells on beta-tricalcium phosphate/poly (l-lactic acid/caprolactone) three-dimensional scaffolds," Journal of Tissue Engineering, vol. 3, no. 1, pp. 1-11, 2012.

[140] P. N. Taşli, S. Aydin, M. E. Yalvaç, and F. Şahin, "Bmp 2 and Bmp 7 induce odonto- and osteogenesis of human tooth germ stem cells," Applied Biochemistry and Biotechnology, vol. 172, no. 6, pp. 3016-3025, 2014.

[141] C. Palumbo, A. Baldini, F. Cavani et al., "Immunocytochemical and structural comparative study of committed versus multipotent stem cells cultured with different biomaterials," Micron, vol. 47, pp. 1-9, 2013.

[142] M. Zavatti, E. Resca, L. Bertoni et al., "Ferutinin promotes proliferation and osteoblastic differentiation in human amniotic fluid and dental pulp stem cells," Life Sciences, vol. 92, no. 2021, pp. 993-1003, 2013.

[143] A. Akkouch, Z. Zhang, and M. Rouabhia, "Engineering bone tissue using human dental pulp stem cells and an osteogenic collagen-hydroxyapatite-poly (l-lactide-co-epsiloncaprolactone) scaffold," Journal of Biomaterials Applications, vol. 28, no. 6, pp. 922-936, 2014.

[144] L. R. Amir, D. F. Suniarti, S. Utami, and B. Abbas, "Chitosan as a potential osteogenic factor compared with dexamethasone in cultured macaque dental pulp stromal cells," Cell and Tissue Research, vol. 358, no. 2, pp. 407-415, 2014.

[145] T. Guo, Y. Li, G. Cao et al., "Fluorapatite-modified scaffold on dental pulp stem cell mineralization," Journal of Dental Research, vol. 93, no. 12, pp. 1290-1295, 2014.

[146] C. E. Huang, F. W. Hu, C. H. Yu, L. L. Tsai, T. H. Lee, M. Y. Chou et al., "Concurrent expression of Oct4 and nanog maintains mesenchymal stem-like property of human dental pulp cells," International Journal of Molecular Sciences, vol. 15, no. 10, pp. 18623-18639, 2014.

[147] J. Jensen, D. C. E. Kraft, H. Lysdahl et al., "Functionalization of polycaprolactone scaffolds with hyaluronic acid and $\beta$-TCP facilitates migration and osteogenic differentiation of human dental pulp stem cells in vitro," Tissue Engineering A, 2014.

[148] J. Ji, W. Sun, W. Wang, T. Munyombwe, and X. B. Yang, "The effect of mechanical loading on osteogenesis of human dental pulp stromal cells in a novel in vitro model," Cell and Tissue Research, vol. 358, no. 1, pp. 123-133, 2014.

[149] M. M. Kanafi, A. Ramesh, P. K. Gupta, and R. R. Bhonde, "Dental pulp stem cells immobilized in alginate microspheres for applications in bone tissue engineering," International Endodontic Journal, vol. 47, pp. 687-697, 2014.

[150] P. N. Taşlı,, A. Doğan, S. Demirci, and F. Şahin, "Boron enhances odontogenic and osteogenic differentiation of human tooth germ stem cells (hTGSCs) in vitro," Biological Trace Element Research, vol. 153, no. 1-3, pp. 419-427, 2013.

[151] A. Woloszyk, S. H. Dircksen, N. Bostanci et al., "Influence of the mechanical environment on the engineering of mineralised tissues using human dental pulp stem cells and silk fibroin scaffolds," PLoS ONE, vol. 9, no. 10, Article ID el11010, 2014.
[152] I. C. Gay, S. Chen, and M. MacDougall, "Isolation and characterization of multipotent human periodontal ligament stem cells," Orthodontics \& Craniofacial Research, vol. 10, no. 3, pp. 149-160, 2007.

[153] O. Trubiani, A. Scarano, G. Orsini et al., "The performance of human periodontal ligament mesenchymal stem cells on xenogenic biomaterials," International Journal of Immunopathology and Pharmacology, vol. 20, no. 1, pp. 87-91, 2007.

[154] Y. Zhou, D. W. Hutmacher, V. Sae-Lim, Z. Zhou, M. Woodruff, and T. M. Lim, "Osteogenic and adipogenic induction potential of human periodontal cells," Journal of Periodontology, vol. 79, no. 3, pp. 525-534, 2008.

[155] M. Orciani, O. Trubiani, A. Vignini, M. Mattioli-Belmonte, R. Di Primio, and E. Salvolini, "Nitric oxide production during the osteogenic differentiation of human periodontal ligament mesenchymal stem cells," Acta Histochemica, vol. 111, no. 1, pp. 15-24, 2009.

[156] B. Zhang, Y. Li, Q. Zhou, and Y. Ding, "Estrogen deficiency leads to impaired osteogenic differentiation of periodontal Ligament stem cells in rats," Tohoku Journal of Experimental Medicine, vol. 223, no. 3, pp. 177-186, 2011.

[157] S. Ge, N. Zhao, L. Wang et al., "Bone repair by periodontal ligament stem cell-seeded nanohydroxyapatite-chitosan scaffold," International Journal of Nanomedicine, vol. 7, pp. 5405-5414, 2012.

[158] L. Sununliganon and W. Singhatanadgit, "Highly osteogenic PDL stem cell clones specifically express elevated levels of ICAM1, ITGB1 and TERT," Cytotechnology, vol. 64, no. 1, pp. 5363, 2012.

[159] B. Houshmand, H. Behnia, A. Khoshzaban et al., "Osteoblastic differentiation of human stem cells derived from bone marrow and periodontal ligament under the effect of enamel matrix derivative and transforming growth factor-beta," The International Journal of Oral \&Maxillofacial Implants, vol. 28, no. 6, pp. e440-e450, 2013.

[160] H. Kato, N. Katayama, Y. Taguchi, K. Tominaga, M. Umeda, and A. Tanaka, "A synthetic oligopeptide derived from enamel matrix derivative promotes the differentiation of human periodontal ligament stem cells into osteoblast-like cells with increased mineralization," Journal of Periodontology, vol. 84, no. 10, pp. 1476-1483, 2013.

[161] S. Y. Kim, J.-Y. Lee, Y.-D. Park, K. L. Kang, J.-C. Lee, and J. S. Heo, "Hesperetin alleviates the inhibitory effects of high glucose on the osteoblastic differentiation of periodontal ligament stem cells," PLoS ONE, vol. 8, no. 6, Article ID e67504, 2013.

[162] X. Kong, Y. Liu, R. Ye et al., "GSK3beta is a checkpoint for TNF-alpha-mediated impaired osteogenic differentiation of mesenchymal stem cells in inflammatory microenvironments," Biochimica et Biophysica Acta-General Subjects, vol. 1830, no. 11, pp. 5119-5129, 2013.

[163] W. Singhatanadgit and M. Varodomrujiranon, "Osteogenic potency of a 3-dimensional scaffold-free bonelike sphere of periodontal ligament stem cells in vitro," Oral Surgery, Oral Medicine, Oral Pathology and Oral Radiology, vol. 116, no. 6, pp. e465-e472, 2013.

[164] S. Yu, J. Long, J. Yu et al., "Analysis of differentiation potentials and gene expression profiles of mesenchymal stem cells derived from periodontal ligament and wharton's jelly of the umbilical cord," Cells Tissues Organs, vol. 197, no. 3, pp. 209-223, 2013.

[165] S. S. Hakki, B. Bozkurt, E. E. Hakki et al., "Bone morphogenetic protein-2, -6 , and -7 differently regulate osteogenic differentiation of human periodontal ligament stem cells," Journal of 
Biomedical Materials Research Part B: Applied Biomaterials, vol. 102, no. 1, pp. 119-130, 2014.

[166] R. Tang, F. Wei, L. Wei, S. Wang, and G. Ding, "Osteogenic differentiated periodontal ligament stem cells maintain their immunomodulatory capacity," Journal of Tissue Engineering and Regenerative Medicine, vol. 8, no. 3, pp. 226-232, 2014.

[167] G. Ye, C. Li, X. Xiang, C. Chen, R. Zhang, X. Yang et al., "Bone morphogenetic protein- 9 induces PDLSCs osteogenic differentiation through the ERK and p38 signal pathways," International Journal of Medical Sciences, vol. 11, no. 10, pp. 1065-1072, 2014.

[168] N. Koyama, Y. Okubo, K. Nakao, and K. Bessho, "Evaluation of pluripotency in human dental pulp cells," Journal of Oral and Maxillofacial Surgery, vol. 67, no. 3, pp. 501-506, 2009.

[169] K. Chadipiralla, J. M. Yochim, B. Bahuleyan et al., "Osteogenic differentiation of stem cells derived from human periodontal ligaments and pulp of human exfoliated deciduous teeth," Cell and Tissue Research, vol. 340, no. 2, pp. 323-333, 2010.

[170] A. Bakopoulou, G. Leyhausen, J. Volk et al., "Assessment of the impact of two different isolation methods on the osteo/odontogenic differentiation potential of human dental stem cells derived from deciduous teeth," Calcified Tissue International, vol. 88, no. 2, pp. 130-141, 2011.

[171] U.-L. Lee, S. H. Jeon, J.-Y. Park, and P.-H. Choung, "Effect of platelet-rich plasma on dental stem cells derived from human impacted third molars," Regenerative Medicine, vol. 6, no. 1, pp. 67-79, 2011.

[172] M. Atari, J. Caballé-Serrano, C. Gil-Recio et al., "The enhancement of osteogenesis through the use of dental pulp pluripotent stem cells in 3D," Bone, vol. 50, no. 4, pp. 930-941, 2012.

[173] A. Moshaverinia, C. Chen, K. Akiyama et al., "Alginate hydrogel as a promising scaffold for dental-derived stem cells: an in vitro study," Journal of Materials Science: Materials in Medicine, vol. 23, no. 12, pp. 3041-3051, 2012.

[174] O. G. Davies, P. R. Cooper, R. M. Shelton, A. J. Smith, and B. A. Scheven, "A comparison of the in vitro mineralisation and dentinogenic potential of mesenchymal stem cells derived from adipose tissue, bone marrow and dental pulp," Journal of Bone and Mineral Metabolism, 2014. 

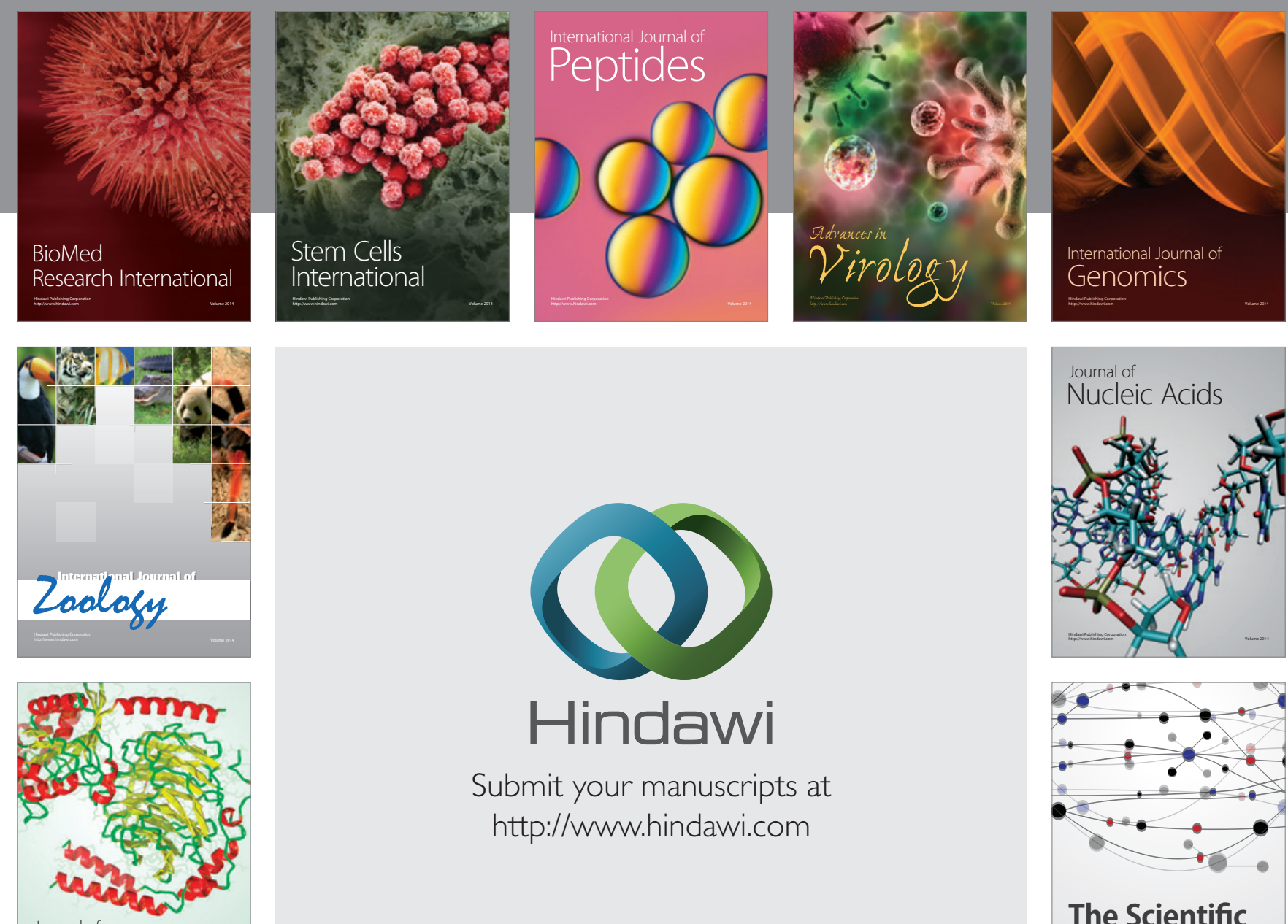

Submit your manuscripts at

http://www.hindawi.com

Journal of
Signal Transduction
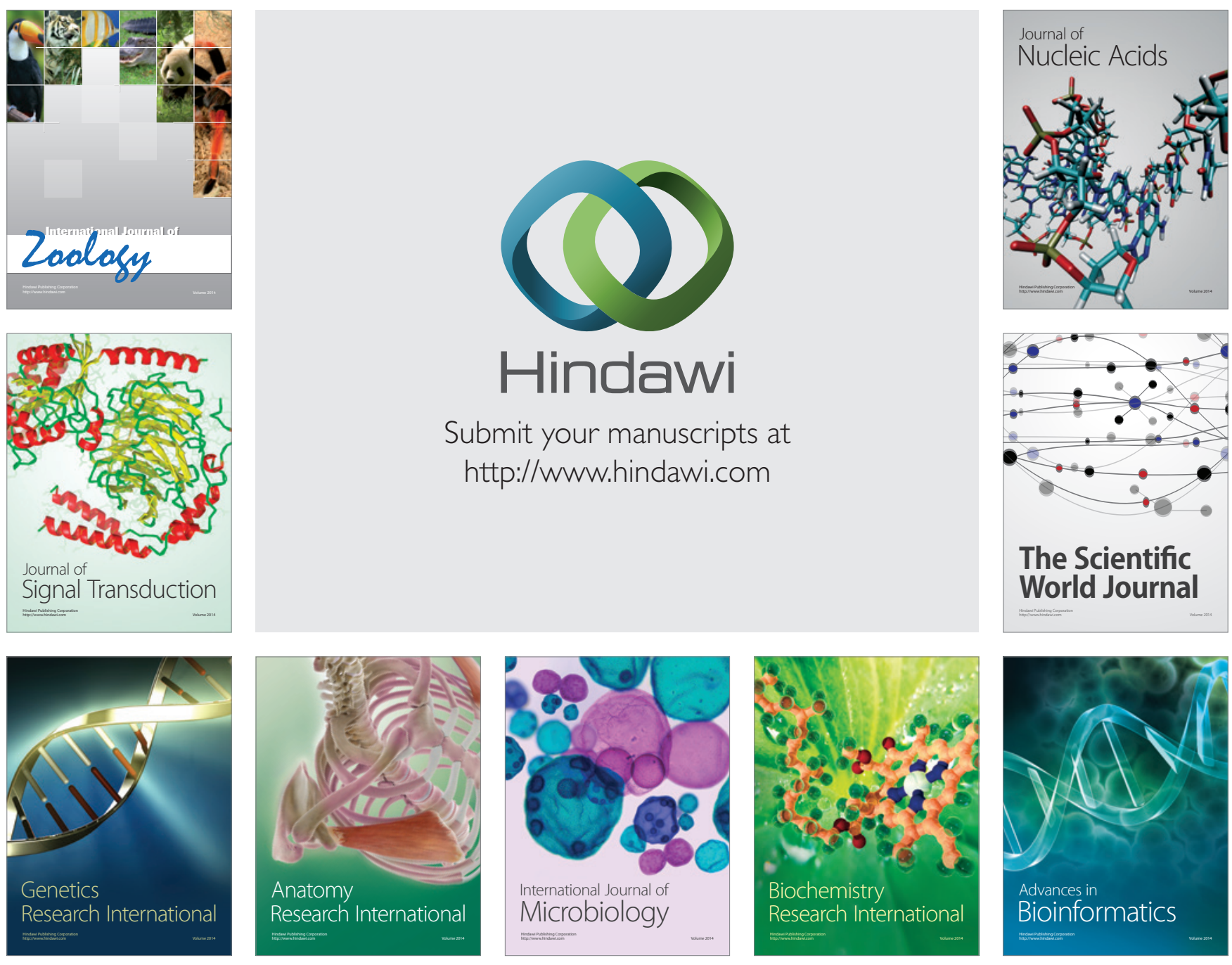

The Scientific World Journal
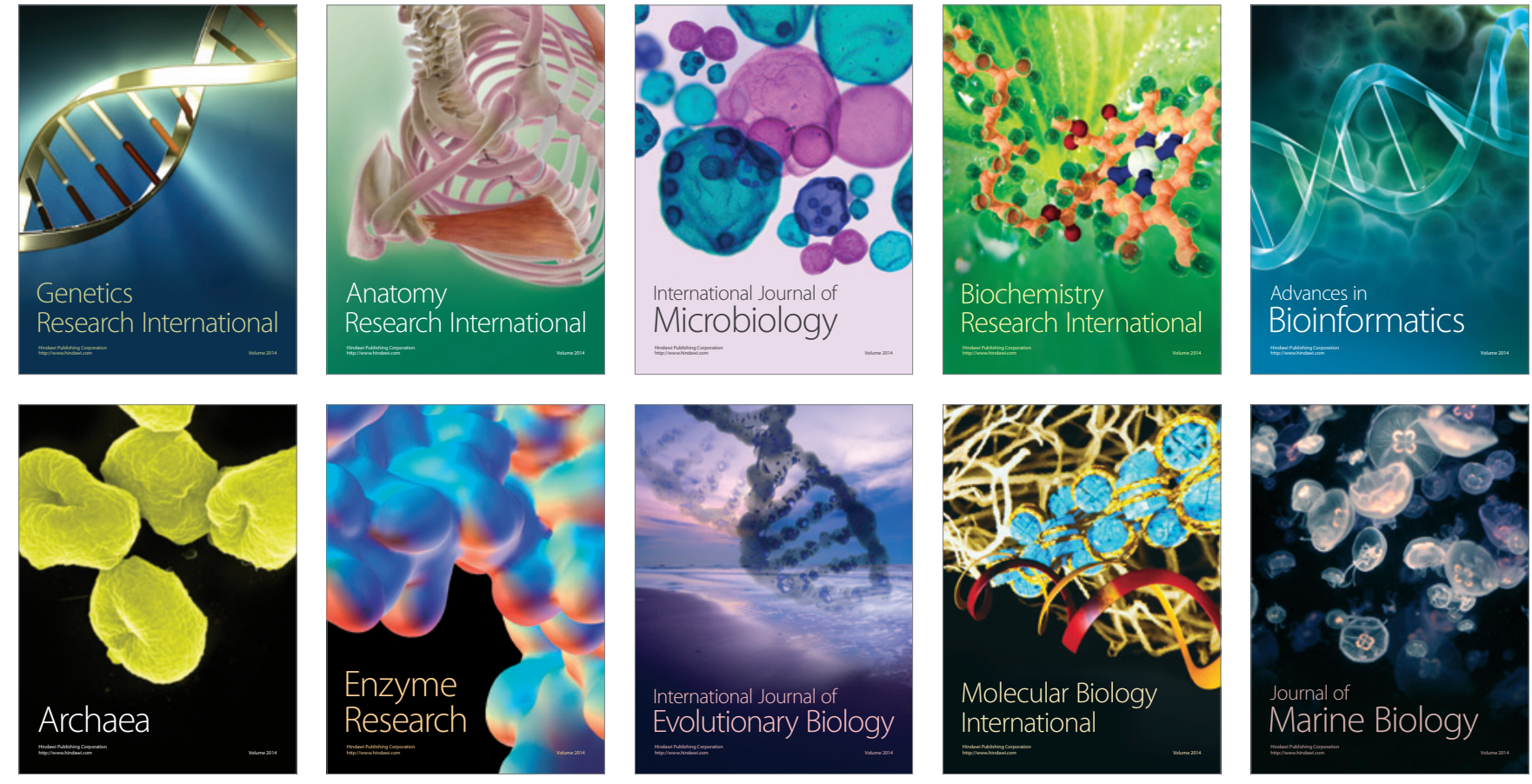